Marquette University

e-Publications@Marquette

$1-1-2015$

\title{
Negativity Bias in Investors' Reactions to Board of Directors' Risk Oversight Disclosure
}

Ikseon Suh

Marquette University, ikseon.suh@marquette.edu

Joseph Ugrin

Marquette University

Accepted version. "Negativity Bias in Investors' Reactions to Board of Directors' Risk Oversight Disclosure" in Advances in Accounting Behavioral Research. Ed. Donna Bobek Schmitt. UK: Emerald 2015: 33-68. DOI. This article is (C) Emerald Group Publishing and permission has been granted for this version to appear here. Emerald does not grant permission for this article to be further copied/ distributed or hosted elsewhere without the express permission from Emerald Group Publishing Limited. 


\title{
Negativity Bias in Investors' Reactions to Board of Directors' Risk Oversight Disclosure
}

\author{
Ikseon Suh \\ Department of Accounting, Marquette University \\ Milwaukee, WI \\ Joseph Ugrin \\ Department of Accounting, Marquette University \\ Milwaukee, WI
}

\begin{abstract}
This study investigates how disclosure of the board of directors' leadership and role in risk oversight (BODs oversight disclosure) influences investors' judgments when information on risk exposures is disclosed. The theoretical lens through which we examine this issue involves negativity bias. Sixty-two stock market investors who engage in the evaluation and/or investment of stocks on a regular or professional basis participated in our study. Our results reveal that the addition of BODs oversight disclosure (positive information) does not carry significant weight on investor judgments (i.e., attractiveness and investment) when financial statement disclosures indicate a high level of operational and financial risk exposures (negative information). In contrast, under the condition of a low level of risk exposures, BODs oversight disclosure causes investors to assess higher risk in terms of worry, catastrophic potentials and unfamiliarity about risk information and, in

Advances in Accounting Behavioral Research, Vol 18 (2015): pg. 33-68. DOI. This article is @ Emerald (JAI Press) and permission has been granted for this version to appear in e-Publications@Marquette. Emerald (JAI Press) does not grant permission for this article to be further copied/distributed or hosted elsewhere without the express permission from Emerald (JAI Press).
\end{abstract}


NOT THE PUBLISHED VERSION; this is the author's final, peer-reviewed manuscript. The published version may be accessed by following the link in the citation at the bottom of the page.

turn, make less favorable investor judgments. Our findings add to the literature on negativity bias and contribute to the debate on the usefulness of disclosures about risk.

Keywords: BODs oversight disclosure; investor judgments; risk-as-feelings; risk disclosures.

Running Title: Negativity Bias in Investors' Reactions

"...As a Commissioner of a disclosure-based agency [former Chairman Laura Unger], I believe that more information is generally better. But is that always the case? (SEC, 2000)"1

\section{Introduction}

The 2008 financial crisis caused investors to critically question the role of boards of directors in managing firms' material risk exposures, including operational and financial risks, and motivated investors to demand more transparency (Kirkpatrick, 2009; Lipton, Neff, Brownstein, Rosenblum, Emmerich, Niles, \& Walker, 2010; Nicholson, 2009). As a response, in late 2009, the U.S. Securities and Exchange Commission (SEC) required publicly traded companies to report information on how their board of directors (BODs) are fulfilling a risk oversight role and interacting with senior executives to oversee enterprise risk management (hereafter BODs oversight disclosure). These disclosure rules are intended to benefit investors in making "informed decisions" (SEC, 2009, p. 4). However, research has paid little attention as to how BODs oversight disclosure influences investor judgments, instead focusing on documenting the state of risk management practices and the BODs risk oversight responsibilities (e.g., Beasley, Branson, \& Hancock, 2010; 2011; Deloitte, 2013; Gates, 2006; Institute of Internal Auditors Research Foundation (IIARF), 2011; Raber, 2003).

In this study, we investigate whether the disclosure of positive information related to the BODs quality and leadership role in risk oversight mitigates the effect of negative information about operational and financial risk exposures (hereafter risk disclosure) on investors' judgments. We examine this issue through the theoretical lens of "negativity bias" (e.g., Baumeister, Bratslavsky, Finkenauer, \& Vohs, 2001). Studies in psychology have demonstrated that negative

Advances in Accounting Behavioral Research, Vol 18 (2015): pg. 33-68. DOI. This article is (C) Emerald (JAI Press) and permission has been granted for this version to appear in e-Publications@Marquette. Emerald (JAI Press) does not grant permission for this article to be further copied/distributed or hosted elsewhere without the express permission from Emerald (JAI Press). 
information related to bad events carries more weight, elicits more information processing, and activates stronger affective reactions in decision making than positive information related to good events (e.g., Fiske, 1980; Ikegami, 1993; Klinger, Barta, \& Maxeiner, 1980;

Öhman, Lundqvist, \& Esteves, 2001; Pratto \& John, 1991). This bias to negative information has also been documented in financial risk analysis. For example, a disclosure of potential risk can elicit a strong affective reaction (Koonce, McAnally, \& Mercer, 2005) and influence investors' assessment of a firm's future performance and their resultant investment decisions (e.g., Fortin \& Berthelot, 2012).

We extend the research on negativity bias by conducting an experiment that investigates how BODs oversight disclosure interacts with risk disclosure and influences investor judgments. Using a $2 \times 2$ between-subjects experiment, we employ a sample of 62 stock market investors who engage in the evaluation and/or investment of stocks on a regular or professional basis (Törngren \& Montgomery, 2004). We present participants with a hypothetical case scenario adapted from a Fortune 500 annual report and proxy statement. In the case scenario, we manipulate the risk disclosure condition as a high or low level of operational and financial risk exposures and the BODs oversight disclosure condition as the absence or presence of information related to the BODs quality and leadership role in risk oversight.

Our results indicate that under the high risk disclosure condition, participants' judgments do not differ significantly when BODs oversight disclosure is present compared to when BODs oversight disclosure is absent. In contrast, when evaluating an investment opportunity under the low risk disclosure condition, participants make less favorable investment judgments in the presence of BODs oversight disclosure than in the absence of BODs oversight disclosure. These results suggest that the disclosure of a high level of risk exposures carries significantly more weight on investment judgments than information about the BODs quality and leadership role in risk oversight. On the other hand, when financial statement disclosures indicate a low level of risk exposures, the addition of BODs oversight disclosure works in a counterintuitive way by amplifying investors' risk perceptions and discouraging investment decisions. Subsequent analyses show that under the low risk

Advances in Accounting Behavioral Research, Vol 18 (2015): pg. 33-68. DOI. This article is @ Emerald (JAI Press) and permission has been granted for this version to appear in e-Publications@Marquette. Emerald (JAI Press) does not grant permission for this article to be further copied/distributed or hosted elsewhere without the express permission from Emerald (JAI Press). 
disclosure condition, the disclosure of BODs role in risk oversight disclosure causes participants to assess risk in affective terms, where feelings of worry, catastrophic potentials, and unfamiliarity about risk information-i.e., Risk-as-Feelings (Slovic, Finucane, Peters, \& MacGregor, 2004)-explain participants' judgments. Overall, our findings suggest that investors do not effectively integrate BODs oversight disclosure information into their judgments when risks are disclosed. The results fail to provide support for the notion that added transparency provided by the BODs oversight disclosure improves investors' decisions.

From a theoretical perspective, this study adds to the literature on negativity bias in the context of risk oversight disclosure and provides support for prior research on negativity bias in investors' decision-making (Cianci \& Falsetta, 2008; Ghosh \& Wu, 2012). From a practical perspective, our findings contribute to the debate on the usefulness of disclosures about risk. This study should be of interest to regulators who are currently evaluating existing disclosure requirements (SEC, 2014) or revising a disclosure framework (FASB, 2014) in response to users' and preparers' concerns about the usefulness of disclosures, the perceived disclosure overload, and the amount of disclosure content.

In the remainder of this chapter we review literature related to risk disclosure, BODs oversight disclosure and negativity bias and put forth our hypotheses. We subsequently explain the methodology used to test the hypotheses and describe the participants, experimental procedures, and the independent and dependent variables. Finally, we report results and discuss their implications, suggest directions for future research, and point out limitations that should be considered when generalizing from our findings.

Advances in Accounting Behavioral Research, Vol 18 (2015): pg. 33-68. DOI. This article is @ Emerald (JAI Press) and permission has been granted for this version to appear in e-Publications@Marquette. Emerald (JAI Press) does not grant permission for this article to be further copied/distributed or hosted elsewhere without the express permission from Emerald (JAI Press). 


\section{Background And Hypotheses Development}

\section{Risk Disclosure and the Board's Leadership and Risk Oversight Role}

In the early 1990s, significant derivative losses resulted from market volatilities in interest rates, foreign currency exchange rates, commodity prices, and equity prices. Those volatile markets, coupled with a lack of adequate disclosure about derivative instruments and their related risks, led investors to demand adequate risk disclosure (Linsmeier \& Pearson, 1997; Schrand \& Elliot, 1998). Since then, regulators have paid considerable attention to promoting and improving transparency regarding risks faced by companies (Linsley \& Shrives, 2006), and firms have increasingly engaged in risk reporting as part of their financial reporting practices (Dobler, 2008). As a result of increased risk reporting among preparers and regulators, research has examined different aspects of risk disclosure such as usefulness (e.g., Bozzolan, Trombetta \& Beretta, 2009), content (e.g., Dia \& Zéghal, 2008), and risk-related corporate governance characteristics (e.g., Abraham \& Cox, 2007).

Additional studies have investigated types of risk categories (e.g., Linsley \& Shrives, 2006), firm size effects on disclosures (e.g., Amran, Bin, \& Hassan, 2009), and the prevalence of qualitative risk reports over quantitative risk information in annual reports (e.g., Dobler, 2008). Further, experimental evidence indicates that investors are less likely to invest in opportunities they feel have greater risk, in particular operational and financial risks or discrete areas of financial risks2 (e.g., Arnold, Bedard, Phillips, \& Sutton, 2012; Dietrich, Kachelmeier, Kleinmuntz, \& Lismeier, 2001; Dobler, 2008; Hirst, Hopkins, \& Wahlen, 2004; Koonce et al., 2005; Lipe, 1998; Olsen, 1997). Despite the efforts of regulators, policy makers, and preparers to ensure adequate risk disclosures, the 2008 financial crisis in the U.S. subprime market and the related liquidity crunch caused investors to become concerned about the BODs role in monitoring enterprise risk management (e.g., Kirkpatrick, 2009; Lipton et al., 2010; Nicholson, 2009).

Advances in Accounting Behavioral Research, Vol 18 (2015): pg. 33-68. DOI. This article is (C) Emerald (JAI Press) and permission has been granted for this version to appear in e-Publications@Marquette. Emerald (JAI Press) does not grant permission for this article to be further copied/distributed or hosted elsewhere without the express permission from Emerald (JAI Press). 
In response, the U.S. Securities and Exchange Commission (SEC) adopted new rules that require publicly traded companies to disclose information regarding their BODs' leadership structure and role in the oversight of enterprise risk management (hereafter BOD oversight disclosure). The SEC's disclosure requirement is intended to increase transparency for "investors as to how the board functions" and improve "investors' and shareholders' understanding about how a company perceives the role of its board and the relationship between the board and senior management in managing material risks [e.g., operational and financial risks] facing the company" (SEC, 2009, p. 42-43). By 2010, most publicly traded companies reported that their BODs directly and actively monitor, to some extent, corporate risks related to their companies' strategic and business decisions (Goldberg \& Harsch, 2010). In those disclosures, firms typically discussed the board's leadership structure and involvement in risk oversight, with an emphasis on the role of a lead director or independent directors in monitoring corporate risks (Akin Gump, Strauss, Hauer, \& Feld LLP, 2010).

To date, research related to BODs oversight disclosure remains rather limited as it primarily provides descriptive data about risk oversight practices. For example, a 2010 COSO-sponsored study reports that $42.2 \%$ of publicly traded companies had assigned a BOD committee with responsibility for risk oversight (Beasley et al., 2010). A 2011 AICPA-sponsored study finds that there has been a noticeable improvement in publicly traded companies' BODs oversight practices, as $62.7 \%$ have a BOD committee monitoring enterprise risk management, but the extent to which the board reviews and discusses top risk exposures in the context of strategic planning tends to be limited (Beasley et al., 2011). A report by the research foundation of the IIARF found that public companies' audit committees are assigned "the oversight responsibilities for $67 \%$ of the risks" (IIARF, 2011, p.17). A 2013 study by Deloitte shows an increasing trend in the percentage of companies with audit committees taking primary responsibility for risk and risk oversight (from 58\% in 2010 to $64 \%$ in 2013), and in the allocation of risk oversight responsibilities among various board committees (from $82 \%$ in 2010 to $91 \%$ in 2013) (Deloitte, 2013). 


\section{The Effect of BODs Oversight Disclosure on Investor Judgments: A Negativity Bias Perspective}

Studies from psychology demonstrate that negative information is more visible or noticeable, carries more weight, activates stronger responses, and has a greater impact on information processing than positive information (e.g., Cacioppo, Berntson, \& Gardner, 1999; Fiske, 1980; Ikegami, 1993; Klinger et al., 1980; Öhman et al., 2001; Pratto \& John, 1991; Slovic, 1993; Smith, Cacioppo, Larsen \& Chartrand, 2003). Greater sensitivity to negative information is known as negativity bias (e.g., Baumeister et al., 2001; Taylor, 1991). In the context of risk analysis, people often assess risky situations by attending to negative information more than positive information. For example, Slovic (1993) found that information on a nuclear plant's potential safety problems, exposure to a series of accidents, and health issue incidences (negative information) had a larger effect on decreasing trust (or increasing risk perception)3 for plant management than the effect of disclosure on the plant's absence of safety problems or health issues (positive information) had on increasing trust. Likewise, the results of a study by MacGregor, Slovic and Morgan (1994) reveal that concerns about health risks increased significantly after subjects read a brochure informing them of potential health risks of electromagnetic fields (negative information) even though they were told that scientific evidence of health risks associated with electromagnetic fields is lacking (positive information).

Evidence-related risk analysis also indicates that negative (or risk) information elicits more intense affective reaction than positive (or benefit) information (e.g., Ito, Larsen, Smith \& Cacioppo, 1998; Slovic et al., 2004). For example, additional risk (or benefit) information amplifies the salience of risks (or benefits) in decision making and changes subjects' affective or favorability assessments in accordance with the direction of risk (or benefit) manipulation information (Finucane, Alhakami, Slovic \& Johnson, 2000). Further, empirical evidence related to risk disclosures reveals that a potential loss outcome associated with disclosed financial risks elicits strong affective reactions (specifically, feelings of dread), significantly influencing risk perceptions (Koonce et al. 2005) and performance evaluations and investment decisions (Fortin \& Berthelot, 2012).

Advances in Accounting Behavioral Research, Vol 18 (2015): pg. 33-68. DOI. This article is @ Emerald (JAI Press) and permission has been granted for this version to appear in e-Publications@Marquette. Emerald (JAI Press) does not grant permission for this article to be further copied/distributed or hosted elsewhere without the express permission from Emerald (JAI Press). 
Based on prior research, we expect that disclosing potential exposure to a high level of operational and financial risks (hereafter the high risk disclosure condition) will draw investors' attention to the risks disclosed and, in turn, elicit a stronger affective reaction when compared to disclosing potential exposure to a low level of operational and financial risks (hereafter the low risk disclosure condition). This quick and emotional response to risks is known as Risk-as-Feelings (Slovic et al., 2004) and represents investors' risk assessments from an affective perspective (Koonce et al., 2005; Slovic, 1987). Considering the magnitude of effect of high risk disclosure on investors' judgments, we expect that additional disclosure on the BODs oversight role in monitoring enterprise risk management will not mitigate the effect of high risk information on risk assessments (Riskas-Feelings) and, in turn, investor judgments. This is because disclosure of high risk exposures (negative information) will carry more weight in investor judgments than BODs oversight disclosure (positive information). This effect, or lack thereof, has been found in other contexts. For example, Anderson and Maletta (1999) found that risk judgments on material misstatements are greater when auditors are instructed to evaluate audit evidence in a high inherent risk4 context than in a low inherent risk context. Under a high inherent risk condition, auditors' assessment of material misstatement risk does not differ when negative internal control information is evaluated before positive internal control information (or vice versa) suggesting that high inherent risk factors significantly influence auditors' risk judgments and positive internal control information has little effect on risk judgments. Similarly, Su and Chang (2010) report that, as the quantity of negative financial information increases, the purchase intention of investors decreases significantly more for companies with a positive corporate image than for companies with a negative corporate image, showing greater incremental effects of negative financial information on investor judgments in the former context than in the latter context. Based on this discussion, we propose the following hypothesis:

H1: In a high risk disclosure condition, investor judgments in the presence of BODs oversight disclosure will not differ from investor judgments made in the absence of BODs oversight disclosure.

Advances in Accounting Behavioral Research, Vol 18 (2015): pg. 33-68. DOI. This article is @ Emerald (JAI Press) and permission has been granted for this version to appear in e-Publications@Marquette. Emerald (JAI Press) does not grant permission for this article to be further copied/distributed or hosted elsewhere without the express permission from Emerald (JAI Press). 
Under the low risk disclosure condition, contrary to the SEC'S intent of benefitting investors by offering greater transparency, we expect that the addition of BODs oversight disclosure (positive information) will draw investors' attention to potential risk exposures (negative information). This bias to negative information (risks disclosed) resulting from oversight disclosure will likely amplify investors' affective reaction to risks disclosed (Risk-as-Feelings) or assessment of risk exposures, causing them to make less favorable judgments compared to judgments made in the absence of BODs oversight disclosure. This leads to a second hypothesis:

H2: In a low risk disclosure condition, investors will make less favorable judgments in the presence of BODs oversight disclosure than in the absence of BODs oversight disclosure.

Prior research indicates that affective responses to a target or stimulus indirectly influence judgments (Loewenstein \& Lerner, 2003; Lerner \& Keltner, 2000). That is, while deliberating a future action, individuals process cues and anticipate outcomes leading to affective responses. These responses, in turn, influence information processing, where individuals tend to selectively process information that supports their initial affective responses (Bodenhausen, Sheppard, \& Kramer, 1994). Consistent with this view, accounting research has documented that investors' attitudes mediate the relationship between disclosures and investment judgments. For example, Frederickson and Miller (2004) found that non-professional investors (MBA students) in a proforma disclosure condition (both pro-forma earnings and GAAP earnings disclosed) assess an earnings announcement more favorably and, in turn, judge stock prices higher than those in a GAAP earnings disclosure condition. Further analysis indicates that non-professional investors' attitudes (i.e., perceived favorableness) about an earnings announcement mediate the relationship between pro-forma disclosures and stock price judgments.

Building from Frederickson and Miller (2004), Victoravich (2010) found that investors' affective reaction to a GAAP earnings announcement (current year earnings increased 15\%) mediates the effect of investor experience level on stock price judgments.

Advances in Accounting Behavioral Research, Vol 18 (2015): pg. 33-68. DOI. This article is @ Emerald (JAI Press) and permission has been granted for this version to appear in e-Publications@Marquette. Emerald (JAI Press) does not grant permission for this article to be further copied/distributed or hosted elsewhere without the express permission from Emerald (JAI Press). 
Specifically, unsophisticated investors (undergraduate non-accounting students) assess earnings announcement more favorably and, in turn, assess stock prices higher, than sophisticated investors (MBA students). The influence of affective state on judgments appears to occur more often in situations of low risk, where subjects have a low need for cognition and rely on simple judgment processes, than in situations of high risks (e.g., Anderson \& Maletta, 1999; Maletta, 1993; Maletta \& Kida, 1993). For example, Rose (2001) found that the recall patterns of subjects with a low need for cognition are influenced more by induced affective states (i.e., sad or happy mood) than the recall patterns of subjects with a high need for cognition. Consistent with this finding, Loewenstein, Weber, Hsee and Welch (2001, p. 274) noted that "...feelings [affective reaction to a situation] may be more than just an important input into decision making under uncertainty; they may be necessary and, to a large degree, mediate the connection between the cognitive evaluation of risk and risk-related behavior..."

Drawing from this research, we expect that, under the low risk disclosure condition, the effect of BODs oversight disclosure on investor judgments will be accounted for by investors' affective reaction to risks disclosed-i.e., Risk-as-Feelings or risk assessment from an affective perspective (Koonce et al., 2005; Slovic, 1987; Slovic et al., 2004). This leads to a third hypothesis:

H3: In a low risk disclosure condition, Risk-as-Feelings will mediate the impact of BODs oversight disclosure on investor judgments.

Figure 1 graphically illustrates the relationship between the constructs and operationalized variables proposed in the hypotheses.

[Insert Figure 1 here]

\section{Research Method}

We perform an experiment with a $2 \times 2$ between-subjects design where we manipulate the risk disclosure condition as a high or low level of operational and financial risk exposures and the BODs oversight disclosure condition as the absence or presence of information about the board's leadership structure and role in 
monitoring enterprise risk management. Outcome measures included participants' risk perceptions from an affective perspective (Risk-asFeelings), attention to disclosure and financial information, and ultimately investor judgments. Descriptions of the participants, experimental procedures, and measurement of the independent and dependent variables are provided in detail in subsequent sections.

\section{Participants}

We test our hypotheses with an experiment involving 62 stock market investors who engage in the evaluation and/or investment of stocks on a regular or professional basis (Törngren \& Montgomery, 2004, p. 150).5 Participation was obtained through contacts developed in coordination with an advisory board of the School of Business of a public university located in the mid-western United States. In total, 73 participants voluntarily accepted our invitation, but nine did not fully complete the task and two did not accurately respond to manipulation check items. After eliminating these eleven participants, the final sample consisted of 62 participants (41 males), all working in areas that involve evaluation of and/or investment in stocks on a regular or professional basis, with a mean years of investment experience of 12.16 years. Demographic data for the sample are summarized in Table 1.

The 62 participants were randomly assigned across the four treatment conditions. We performed chi-square analyses and a oneway ANOVA on the demographic data (Gender, Type of Employer, Years of Investment Experience, Undergraduate Major and Graduate Major). Table 1 shows that demographic factors do not differ significantly across treatment conditions (all $p>0.05$ ), and that Investor Judgments across demographic factors do not yield any significant relationship (all $p>0.05$ )6, except for Undergraduate Major ( $p=0.077$ ) (not tabulated).7 A correlation analysis (see Table 6 in subsequent sections) shows that Years of Investment Experience does not significantly correlate with Investor Judgments $(p>0.10)$. Considering these results, our participants' demographic profile appears to be adequately balanced across treatment conditions and demographic factors are not significantly related to outcome measures. Thus, we do not include demographic factors in further tests.

Advances in Accounting Behavioral Research, Vol 18 (2015): pg. 33-68. DOI. This article is @ Emerald (JAI Press) and permission has been granted for this version to appear in e-Publications@Marquette. Emerald (JAI Press) does not grant permission for this article to be further copied/distributed or hosted elsewhere without the express permission from Emerald (JAI Press). 
NOT THE PUBLISHED VERSION; this is the author's final, peer-reviewed manuscript. The published version may be accessed by following the link in the citation at the bottom of the page.

[Insert Table 1 here]

\section{Experimental Materials and Procedures}

Participants were presented with paper-based case material8 in individual sessions. They were not compensated and did not face any time limits. The case scenario was based on the annual report of a Fortune 500 company (a food manufacturing company) and a proxy statement with detailed information about risk exposures and the BOD leadership structure and role in risk oversight. The actual name of the Fortune 500 Company was replaced with a hypothetical name. This approach is similar to that used by prior research examining investors' judgment and decision making (e.g., Frederickson \& Miller, 2004; Miller \& Sedor, 2014).

All participants were provided with the hypothetical company's background information, including the company's profile and a summary of three-year financial indicators, and information on the company's exposures to Operational Risk, Financial Risk, and Other Risks. One group of participants received high risk disclosure information and another group of participants received low risk disclosure information. See Appendix A for a description of risk disclosure information. Irrespective of risk disclosure condition, participants received the same information on Other Risks. After learning the company's risk exposures (high or low), one group of participants indicated their perceptions of the company's risk exposures (i.e., the absence of BODs oversight disclosure condition) while the other group of participants read the BODs oversight disclosure and then assessed the company's risk exposures. See Appendix B for a description of BODs oversight disclosure information. Next, participants across all conditions received the same five-year financial summary information related to the company and were then instructed to make their investment judgments (i.e., attractiveness and investment). Upon the completion of the experimental task, participants responded to demographic questions, manipulation check items, and a number of debriefing items. See Table 2 for more information on the experimental procedures.

[Insert Table 2 here]

Advances in Accounting Behavioral Research, Vol 18 (2015): pg. 33-68. DOI. This article is @ Emerald (JAI Press) and permission has been granted for this version to appear in e-Publications@Marquette. Emerald (JAI Press) does not grant permission for this article to be further copied/distributed or hosted elsewhere without the express permission from Emerald (JAI Press). 
NOT THE PUBLISHED VERSION; this is the author's final, peer-reviewed manuscript. The published version may be accessed by following the link in the citation at the bottom of the page.

\section{Measures}

\section{Dependent Variable: Investor Judgments}

To measure investor judgments, we employed approaches similar to those used by Lipe (1998) and Holt and DeZoort (2009). Specifically, we asked participants to indicate with what degree of attractiveness they viewed the hypothetical company's stock as an investment opportunity ( 0 = not attractive, 100 = highly attractive) (Attractiveness), and how likely they would be to invest in the hypothetical company's stock ( $0=$ not at all likely, $100=$ extremely likely) (Investment). Before hypotheses testing, we combined the Attractiveness and Investment items into one measure (referred to as Investor Judgments) because they are significantly correlated ( $\hat{\rho}=$ $0.861, p<0.001$ ). The Cronbach's Alpha (reliability statistics) of the combined measure is 0.923 .

\section{Independent Variable: Risk Disclosures}

Financial risk is the most prevalent category of risk disclosure across the 160 listed firms 9 in the manufacturing sector of the U.S., Canada, U.K., and Germany, followed by market risk and operational risk categories as well as non-financial category risks (Dobler, Lajili, \& Zéghal, 2011; Lajili \& Zéghal, 2005). To simulate a realistic scenario based on an all-inclusive approach, participants were provided with disclosure information about Operational and Financial risks as well as Other Risks (i.e., non-financial risks).10 The risk disclosure information (i.e., Operational, Financial, and Other Risks) was based on the annual report of a Fortune 500 company (a food manufacturing company). We manipulated the operational and financial categories of risk as high or low by using sensitivity analysis. This approach is similar to that of Koonce et al. (2005) and provides explicit estimates of the potential losses in future earnings, cash flows, or equity that arise from the failure to manage risk exposures (Rajgopal, 1999). See Appendix A for a more detailed description of the risk disclosure manipulation.

Independent Variable: Board of Directors' Oversight Disclosure

Advances in Accounting Behavioral Research, Vol 18 (2015): pg. 33-68. DOI. This article is @ Emerald (JAI Press) and permission has been granted for this version to appear in e-Publications@Marquette. Emerald (JAI Press) does not grant permission for this article to be further copied/distributed or hosted elsewhere without the express permission from Emerald (JAI Press). 
The manipulation of the board's role in risk oversight consisted of the exclusion (absence) or inclusion (presence) of BODs oversight disclosure. For the latter case, we used information about the board's leadership structure and role in monitoring enterprise risk management (ERM) from the proxy statement of the same Fortune 500 company, as it clearly provides information mandated by the SEC. For specific information on BODs oversight disclosure, see Appendix B. In addition, information on the board's makeup, characteristics, and attendance at annual board meetings was presented $11 \mathrm{n}$ because this information is included in the proxy statement and because prior research has found that investors' perception of the board's effectiveness is influenced by its independence (Beasley \& Petroni, 2001), financial expertise (Gendron \& Bédard, 2006; Norman, Rose, \& Suh, 2011; Sharma, 2006), size (Anderson, Mansi, \& Reeb, 2004) and number of annual meetings (Chen \& Zhou, 2007).

\section{Mediating Variables: Risk Perceptions}

To measure risk perceptions, we incorporated the items utilized by Koonce et al. (2005). These items covered participants' perceptions of: loss outcome (LossOutcome), loss probability (LossProbability), gain outcome (GainOutcome), gain probability (GainProbability), probability of neither an economic gain nor an economic loss (StatusQuo), precise knowledge of the risk by the participant (ParticipantKnow), precision of management's knowledge of the risk (ManagementKnow), management's ability to limit the risk (Control), worry (Worry), the catastrophic nature of potential loss (Catastrophic), and newness of the risk (Newness). 12 Next, we conducted a confirmatory factor analysis to combine the items into distinct factors of risk assessment. This analysis resulted in a three -factor solution.13 The factor loadings are displayed in Table 3. Factor one is titled Riskas-Analysis and includes perceptions of LossOutcome, LossProbability, GainOutcome, and GainProbability, all representing risk perception from the decision-theory perspective (Koonce et al., 2005). That is, risk judgments were analyzed and evaluated though the use of "algorithms and normative rules, such as probability calculus or formal logic" (Slovic, 1987; Slovic et al., 2004). Factor two is titled Risk-asControl and includes perceptions of ParticipantKnow, ManagementKnow, and Control, all representing perceived 
controllability of risk (Koonce et al., 2005; Slovic, 1987). Factor three is titled Risk-as-Feelings and includes perceptions of Worry, Catastrophic, and Newness, all representing risk perception from an affective perspective (Slovic, 1987; Slovic et al., 2004). Cronbach's alpha for all three factors was acceptable (all $\geq 0.790$ ) (Table 3). The main variables and measures are summarized in Table 4.

[Insert Tables 3 and 4 here]

\section{Analysis And Results}

\section{Manipulation Check}

Results of a $t$-test show that the risk manipulation was successful, as participants, on average, perceived the overall risk exposure (OverallRisk) (Table 5 ) to be significantly higher ( $t=-4.579$, $p<0.01$ ) in the high risk disclosure condition (Mean $=61.83$, s.d. $=$ $13.02, \mathrm{n}=30$ ) than in the low risk disclosure condition (Mean = 47.13 , s.d. $=12.05, \mathrm{n}=32$ ).

\section{Descriptive Statistics and Correlation Analysis}

We performed ANOVA tests and correlation analyses on key variables to evaluate differences across treatment conditions and provide a preliminary evaluation of relationships. Table 5 reveals that participants under the low risk disclosure condition, on average, perceive less risk (Risk-as-Analysis, Risk-as-Feelings, and Risk-asControl) and made more favorable investment judgments than participants under the high risk disclosure condition. Results in Table 6 confirm the positive correlation between the risk manipulation condition and participants' risk judgments. Further, Investor Judgments are negatively correlated with Risk Disclosure ( $p=0.001)$, BODs Oversight Disclosure $(p=0.056)$, Risk-as-Analysis $(p=0.059)$, and Risk-as-Feelings $(p=0.001)$.

[Insert Tables $5 \& 6$ here]

Advances in Accounting Behavioral Research, Vol 18 (2015): pg. 33-68. DOI. This article is @ Emerald (JAI Press) and permission has been granted for this version to appear in e-Publications@Marquette. Emerald (JAI Press) does not grant permission for this article to be further copied/distributed or hosted elsewhere without the express permission from Emerald (JAI Press). 


\section{Test of Hypotheses 1 and 2: The Impact of BODs Oversight Disclosure on Investor Judgments}

We performed a $2 \times 2$ ANOVA with Investor Judgments as the dependent variable and Risk Disclosure (high versus low risk exposures) and BODs Oversight Disclosure (absence versus presence) as independent variables. Table 7, Panel $B$, and Figure 2 show significant main effects of Risk Disclosure $(F=12.550, p<0.01)$ and $B O D s$ Oversight Disclosure $(F=4.102, p=0.047)$ and a significant interaction ( $F=6.597, p=0.013)$ between Risk Disclosure and BODs Oversight Disclosure on participants' Investor Judgments.

[Insert Table 7 and Figure 2 here]

To gain a better understanding of differences in Investor Judgments, we performed planned contrast tests on Investor Judgments across the four treatment conditions: LR (Low Risk Disclosed)/Absence (of BODs Oversight Disclosure), LR/Presence (of $B O D s$ Oversight Disclosure), HR (High Risk Disclosed)/Absence, and $\mathrm{HR} /$ Presence. The coefficients for the contrast between LR/Absence and LR/Presence (or HR/Absence and HR/Presence) are -1 and +1 , respectively, and for the remaining treatment conditions are 0 . Under the high risk exposure condition, our results (not tabulated) failed to indicate significant differences in participants' Investor Judgments ( $t=$ $0.378, p=0.706$ ) between the presence of BODs Oversight Disclosure (Mean $=81.13$, s.d. $=19.53)$ and the absence of BODs Oversight Disclosure (Mean $=77.27$, s.d. $=31.02$ ). In contrast, under the low risk exposure condition, participants' Investor Judgments in the presence of BODs Oversight Disclosure (Mean $=88.07$, s.d. $=22.78)$ were significantly less $(t=-3.299, p=0.002)$ than participants' Investor Judgments in the absence of BODs Oversight Disclosure $($ Mean $=120.76$, s.d. $=34.76)$. These results support hypotheses 1 and 2. 


\section{Test of Hypothesis 3: The Mediating Role of Risk-As- Feelings in Investor Judgments}

To test hypothesis 3, we performed a one-way ANOVA and Tukey's HSD test across the four treatment conditions and found significant mean differences only in Risk-as-Feelings under the low risk disclosure condition. Specifically, the mean of Risk-as-Feelings in the absence of BODs Oversight Disclosure was significantly lower (Mean = 83.9 , s.d. $=23.1$ ) compared to the mean of Risk-as-Feelings in the presence of BODs Oversight Disclosure (Mean = 121.3, s.d. $=37.5)(p$ $<0.05)$. In contrast, under the high risk disclosure condition, Risk-asFeelings (Mean $=178.5$, s.d. $=47.8$ ) in the absence of BODs Oversight Disclosure did not differ significantly $(p=0.907)$ from Riskas-Feelings (Mean $=169.3$, s.d. $=39.9$ ) in the presence of BODs Oversight Disclosure. Likewise, as shown in Table 5, differences in the mean of Risk-as-Analysis or Risk-as-Control from the absence of BODs Oversight Disclosure to the presence of BODs Oversight Disclosure were not significant (all $p>0.10$ ), irrespective of high or low risk disclosure condition. These results support our underlying assumption that the addition of BODs oversight disclosure will amplify investors' affective reactions to risk information when financial statement disclosures indicate exposures to a low level of operational and financial risks.

A mediation analysis was subsequently performed as outlined in Baron and Kenny (1986). Our results for the combined data for both the high and low Risk Disclosure conditions show no significant relationships between BODs Oversight Disclosure and Risk-as-Analysis, Risk-as-Feelings, or Risk-as-Control (all $p>0.05$ ). Due to the lack of significant relationships, results are not tabulated for the combined data. Following the initial analysis, we performed the mediation tests on the data split according to high and low Risk Disclosure conditions. Under the high Risk Disclosure condition, we do not find a significant association between BODs Oversight Disclosure and Investor Judgments ( $p=0.686$ ) or between BODs Oversight Disclosure and Risk-as-Analysis ( $p=0.756)$, Risk-as-Feelings $(p=0.569)$ or Risk-asControl ( $p=.939)$. These results reveal that none of the risk assessments from the affective perspective (Risk-as-Feelings), the perspective of perceived controllability of risk (Risk-as-Control) or the

Advances in Accounting Behavioral Research, Vol 18 (2015): pg. 33-68. DOI. This article is @ Emerald (JAI Press) and permission has been granted for this version to appear in e-Publications@Marquette. Emerald (JAI Press) does not grant permission for this article to be further copied/distributed or hosted elsewhere without the express permission from Emerald (JAI Press). 
decision-theory perspective (Risk-as-Analysis) account for the relationship between BODs Oversight Disclosure and Investor Judgments, and that positive information on boards' leadership and role in risk oversight did not influence Investor Judgments.

In contrast, under the low Risk Disclosure condition, only Riskas-Feelings fully mediates the relationship between BODs Oversight Disclosure and Investor Judgments (Sobel test statistic $=2.6349, p=$ $0.008)$. Specifically, the results show significant relationships between BODs Oversight Disclosure and Risk-as-Feelings ( $p<0.05)$ (p21 in Figure 3), between Risk-as-Feelings and Investor Judgments (p32 in Figure 3), and between BODs Oversight Disclosure and Investor Judgments $(p<0.05)$ (p31 in Figure 3$)$. When we control for Risk-asFeelings in the models, we find that the relationship between BODs Oversight Disclosure and Investor Judgments was not significant (both $p>0.05$ ) (p31' in Figure 3). These results support hypothesis 3 and suggest that BODs oversight disclosure causes investors to worry and perceive catastrophes and unfamiliarity about risk exposures, and make Investor Judgments based on their feelings toward risks disclosed rather than on an analytical assessment of risk or perception of risk controllability.

[Insert Figure 3 here]

\section{Supplementary Analyses}

To evaluate the potential for attention to negative information in the context of risk disclosure, we performed a $t$-test on Information Usage per each category of information disclosure. Results in Table 8, Panel A, indicate that the usage of Risk Disclosure information for making investment decisions is significantly greater in the high Risk Disclosure condition than in the low Risk disclosure condition ( $t=$ 3.529, $p=0.001$ ). Further, the usage of Operational and Financial Risk Disclosure is significantly greater in the high Risk Disclosure condition than in the low Risk Disclosure condition ( $t=3.405, p=$ $0.001)$. In contrast, the difference in the usage of Other Risk Disclosure is insignificant ( $t=-0.948, p=0.347$ ) across the risk disclosure conditions. These results provide support for the assumption that participants pay more attention to information with a high risk 
outcome than information with a low risk outcome (e.g., Fiske, 1980; Kahneman \& Tversky, 1984; Taylor, 1991) and suggest that Other Risk Disclosure does not contribute to the variation of Investor Judgments (or decrease the internal validity of the study).

We also performed additional $t$-tests on Information Usage between the presence/absence of BODs Oversight Disclosure conditions. Results in Table 8, Panel B, suggest that participants with BODs Oversight Disclosure shifted their attention to oversight disclosure information and focused less attention to other types of information (i.e., risk disclosure and financial ratios) compared to participants without BODs Oversight Disclosure. In addition, regression analysis results in Table 8, Panel $\mathrm{C}$, show that Investor Judgments are not significantly associated with BODs Oversight Disclosure under the high Risk Disclosure condition but are negatively associated with BODs Oversight Disclosure under the low Risk Disclosure condition at a significance level of 0.05 . These results corroborate our findings for hypotheses 1 and 2 .

\section{Conclusion and Discussion}

This study examines whether the disclosure of positive information about BODs quality and leadership role in risk oversight mitigates the effect of negative information about operational and financial risk exposures on investor judgments. We found that the addition of BODs oversight disclosure does not influence investor judgments in the high risk disclosure condition, but causes investor judgments to be less favorable in the low risk disclosure condition. In the latter condition, investors view the investment opportunity less favorably when they learn about the BODs quality and leadership role in risk oversight after being informed of the firm's exposure to operational and financial risks. This counterintuitive result is explained by investors' risk assessment from the affective perspective-i.e., Risk-as-Feelings (Slovic et al., 2004). Further analysis reveals that in the low risk disclosure condition, the addition of BODs oversight disclosure leads investors to judge risk in terms of worry, catastrophic potentials, and unfamiliarity about risk information (Risk-as-Feelings) more than in terms of probabilities and outcome (Risk-as-Analysis) or perceived controllability (Risk-as-Control) and may cause investors to

Advances in Accounting Behavioral Research, Vol 18 (2015): pg. 33-68. DOI. This article is @ Emerald (JAI Press) and permission has been granted for this version to appear in e-Publications@Marquette. Emerald (JAI Press) does not grant permission for this article to be further copied/distributed or hosted elsewhere without the express permission from Emerald (JAI Press). 
make investor judgments based on their feelings toward risks disclosed rather than analytical assessment or perceived controllability of risk.

Results of this study are limited by our experimental design and constraints inherent in experimental research (Shadish, Cook, \& Campbell, 2002), and therefore readers should interpret our results with care. For example, the experimental setting represents an abstraction from reality and may not allow participants to fully engage themselves as if they were in a real investment context with much richer information than that depicted in the case materials. Specifically, our participants were provided with a hypothetical company's financial information, including disclosures on risk information and the BODs risk oversight, in a condensed version. We opted to provide this abridged version to make sure that all required tasks were completed within a reasonable amount of time. Although we pre-tested the instrument to assess if the content of the financial information was realistic and relevant for the task, the compression of financial information does not represent the amount of material that investors would have to process and analyze when making a real investment decision.

Despite these limitations we anticipate that the results of our study will be valued by academics, practitioners, and regulators alike. From a practical perspective, this study contributes to the debate on the usefulness of disclosures. Our findings indicate that positive information about the board's leadership and role in risk oversight is not effectively incorporated into investors' judgment and decisionmaking process, irrespective of a high or low risk disclosure condition, and does not lead investors to make "informed investment decisions" (SEC, 2009, p. 4). Our findings suggest that communicating risk oversight practices, particularly the role of the BODs leadership structure and role in monitoring operational and financial risk management, may also be challenging for firms with low risk exposures. From a theoretical perspective, the findings contribute to the literature on negativity bias in investors' judgments (Cianci \& Falsetta, 2008; Ghosh \& Wu, 2012) in the context of risk and BODs oversight disclosures.

Advances in Accounting Behavioral Research, Vol 18 (2015): pg. 33-68. DOI. This article is @ Emerald (JAI Press) and permission has been granted for this version to appear in e-Publications@Marquette. Emerald (JAI Press) does not grant permission for this article to be further copied/distributed or hosted elsewhere without the express permission from Emerald (JAI Press). 
Researchers may also be interested in extending our study to provide a broader understanding of the effects of risk and BODs oversight disclosures. For example, our participants made investment judgments when BODs oversight information was presented after risk exposure information but not before. It is not clear whether oversight disclosure preceding risk exposure information will result in primacy (e.g., Anderson \& Maletta, 1999; Wilks, 2002) or recency effects on investor judgments (e.g., Ahlawat, 1999; Ashton \& Ashton, 1988). Future research could look into this issue. We also did not examine whether investors suffer from information overload if they were provided with information about risk exposures and BODs oversight disclosure or instructed to find disclosure information in the entire annual report. Future research could gain insight into the specific factors causing disclosure overload between those two conditions and examine the effects of disclosure overload on investors' effort to process information (i.e., risk and BODs oversight disclosure) and their judgment and decision making. Finally, future research could also examine the impact of firm familiarity or non-familiarity versus immediate or delayed availability of BODs oversight disclosure on investors' judgments, as well as identifying mitigating factors that can offset investors' affective reactions or increase investors' reliance on reason-based analysis.

\section{Acknowledgements}

An earlier version of this manuscript was presented at the 2012 AAA meeting. We would like to express our appreciation to Michael Akers, Don Giacomino, Jodi Gissel, Amy Hageman, Bugra Ozel, Jacob Rose, Theresa Presley and John T. Sweeney for their insightful comments and Joseph Wall for his help during the pilot test of this study. We would also like to thank Tyler Krutzfeldt, Valerie Mack, Michael Monaghan, William Schepeler, members of the Kansas State University College of Business Advisory Board, and others who assisted with data collection and recruiting of participants.

\section{Appendix A: Risk Disclosure Manipulation}

Participants received a detailed disclosure of operational risk and a sensitivity analysis of selling, general, and administrative (SGA)

Advances in Accounting Behavioral Research, Vol 18 (2015): pg. 33-68. DOI. This article is @ Emerald (JAI Press) and permission has been granted for this version to appear in e-Publications@Marquette. Emerald (JAI Press) does not grant permission for this article to be further copied/distributed or hosted elsewhere without the express permission from Emerald (JAI Press). 
expenses and cost of goods sold (COGS). The sensitivity analysis for a high (or low) level of operational risk exposure described that a failure to achieve a $10 \%$ reduction in cost savings would cause an economic loss of approximately $40 \%$ (or $1 \%$ in the low risk disclosure condition) on the company's equity and result in severe harm (or 'would not adversely affect' in the low risk disclosure condition) long-term profitability and financial strength.

In addition, participants received a detailed disclosure on financial risk and a sensitivity analysis associated with long-term debts subject to variable interest rates and commodity prices subject to future and option commodity prices.

The sensitivity analysis for a high (or low) level of interest rate risk indicated that a $10 \% 1$ increase in the market interest rate would cause an economic loss of approximately $40 \%$ (or $1 \%$ in the low risk condition) of the company's equity and result in severe harm (or 'would not adversely affect' in the low risk disclosure condition) to long-term profitability and financial strength. The sensitivity analysis for a high (or low) level of commodity price risk indicated that if hedging prices are in excess of spot prices by $10 \%$, this situation would cause an economic loss to the company in the amount of approximately $40 \%$ of the company's equity (or $1 \%$ in the low risk condition).

\section{Appendix B: Board Oversight Of Enterprise Risk}

The Board utilizes our Enterprise Risk Management (ERM) process to assist in fulfilling its oversight of our risks.

Management, which is responsible for day-to-day risk management, conducts a risk assessment of SW's business annually.

o The risk assessment process is global in nature and has been developed to identify and assess SW's risks, including the nature of the risk, as well as to identify steps to mitigate and manage each risk.

o Several hundred of our key business leaders, functional heads and other managers are surveyed and/or interviewed to develop this information.

Advances in Accounting Behavioral Research, Vol 18 (2015): pg. 33-68. DOI. This article is @ Emerald (JAI Press) and permission has been granted for this version to appear in e-Publications@Marquette. Emerald (JAI Press) does not grant permission for this article to be further copied/distributed or hosted elsewhere without the express permission from Emerald (JAI Press). 
NOT THE PUBLISHED VERSION; this is the author's final, peer-reviewed manuscript. The published version may be accessed by following the link in the citation at the bottom of the page.

While risk oversight is a full Board responsibility, the responsibility for monitoring the ERM process has been delegated to the Audit Committee. As such, one of the leaders of the ERM process is the Vice President, Internal Audit, who reports directly to the Chair of the Audit Committee.

The results of the risk assessment are reviewed with the Audit Committee and the full Board:

o The centerpiece of the assessment is the discussion of key risks, which includes the potential magnitude and likelihood of each risk.

As part of the process for each risk, management identifies each one of the following key points:

o The nature of the risk

o The senior executive responsible for managing the risk

o The potential impact

o Management's initiatives to manage the risk

o The most recent Board or Committee update, and

o The timing of the next scheduled Board or Committee review.

In addition to the enterprise-wide assessment, each business unit discusses its risk assessment as part of its annual business plan review with the Board.

The results of the risk assessments are then integrated into the Board's processes.

o Oversight responsibility for each risk is allocated among the full Board and its Committees, and specific Board and Committee agendas are developed accordingly.

Each Committee chair has the following responsibilities:

o Work directly with SW's key senior executive responsible for the matters allocated to the Committee to develop agenda topics

o Review materials to be discussed with the Committee

o Discuss specific topics relating to the particular Committee

Advances in Accounting Behavioral Research, Vol 18 (2015): pg. 33-68. DOI. This article is @ Emerald (JAI Press) and permission has been granted for this version to appear in e-Publications@Marquette. Emerald (JAI Press) does not grant permission for this article to be further copied/distributed or hosted elsewhere without the express permission from Emerald (JAI Press). 
NOT THE PUBLISHED VERSION; this is the author's final, peer-reviewed manuscript. The published version may be accessed by following the link in the citation at the bottom of the page.

Through the above process each key risk is reviewed at least annually, with many topics reviewed on several occasions throughout the year.

Due to the dynamic nature of risk, BODs has taken the following oversight/review actions to fulfill its oversight responsibilities of SW's risks:

o The overall status of SW's enterprise and business unit risks are updated.

o A summary of key risks is reviewed at each Audit Committee meeting and adjustments are made to Board and Committee agendas throughout the year.

\section{References}

Abraham, S. \& Cox, P. (2007). Analyzing the determinants of narrative risk information in UK FTSE 100 annual reports. The British Accounting Review, 39, 227-248.

Ahlawat, S. (1999). Order effects and memory for evidence in individual versus group decision making in auditing. Journal of Behavioral Decision Making, 12 (1), 71-88.

Akin Gump, Strauss, Hauer \& Feld LLP. (2010). The Board's Role in Risk Oversight: A Survey of Recent Proxy Statement Disclosures. Corporate Alert, April.

American Institute of Certified Public Accountants (AICPA), Accounting Standards Executive Committee. (1994). Disclosure of Certain Significant Risks and Uncertainties. Statement of Position No. 94-6. New York, NY: AICPA.

American Institute of Certified Public Accountants. (2006). Audit Risk and Materiality in Conducting an Audit. Statement on Auditing Standards No. 107. New York, NY: AICPA.

Amran, A., Bin, A. \& Hassan, B. (2009). Risk reporting: An exploratory study on risk management disclosure in Malaysian annual reports. Managerial Auditing Journal, 24(1), 39-57.

Anderson, B. \& Maletta, M. (1999). Primacy effects and the role of risk in auditor belief-revision process. Auditing: A Journal of Practice and Theory, 18(1), 76-89.

Anderson, R., Mansi, S. \& Reeb, D. (2004). Board characteristics, accounting report integrity, and the cost of debt. Journal of Accounting and Economics, 37(1), 315-42.

Arnold, V., Bedard, J., Phillips, J. \& Sutton, S. (2012).The impact of tagging qualitative financial information on investor decision making:

Advances in Accounting Behavioral Research, Vol 18 (2015): pg. 33-68. DOI. This article is @ Emerald (JAI Press) and permission has been granted for this version to appear in e-Publications@Marquette. Emerald (JAI Press) does not grant permission for this article to be further copied/distributed or hosted elsewhere without the express permission from Emerald (JAI Press). 
NOT THE PUBLISHED VERSION; this is the author's final, peer-reviewed manuscript. The published version may be accessed by following the link in the citation at the bottom of the page.

Implications for XBRL .International Journal of Accounting Information Systems, 13, 2-20.

Ashton, A.H. \& Ashton, R.H. (1988). Sequential Belief Revision in Auditing. The Accounting Review, 63(4), 623-641.

Baron, R., \& Kenny, D. (1986). The moderator-mediator variable distinction in social psychological research: Conceptual, strategic, and statistical considerations. Journal of Personality and Social Psychology, 51(6), 1173-1182.

Baumeister RF, Bratslavsky E, Finkenauer C, \& Vohs KD. (2001). Bad is stronger than good. Review of General Psychology, 5, 323-70.

Beasley, M., Branson, B. \& Hancock, B. (2010). Are you identifying your most significant risks? Strategic Finance, November, 29-35.

Beasley, M., Branson, B. \& Hancock, B. (2011). Report on the Current State of Enterprise Risk Oversight. Research conducted by the ERM initiative at NC State. AICPA, 3rd Edition, 1-30. Retrieved from http://www.aicpa.org/interestareas/businessindustryandgovernment/r esources/erm/downloadabledocuments/current_state_erm_3rdedition. pdf

Beasley, M., \& Petroni, K. (2001). Board independence and audit-firm type. Auditing: A Journal of Practice \& Theory 20 (1), 97-114.

Bodenhausen, G., Sheppard, L. \& Kramer, G. (1994). Negative affect and social judgment: The differential impact of anger and sadness. European Journal of Social Psychology, 24(1), 45-62.

Bozzolan, S., Trombetta, M. \& Beretta, S. (2009). Forward-looking disclosures, financial verifiability, and analysts' forecasts: A study of cross-listed European firms. European Accounting Review, 18(3), 435473.

Cacioppo, J. T., Berntson, G.G., \& Gardner, W.L. (1999). The affect system has parallel and integrative processing components: Form follows function. Journal of Personality and Social Psychology, 76(5), 839-855.

Chen, K. \& Zhou, J. (2007). Audit committee, board characteristics, and auditor switch decisions by Andersen's clients. Contemporary Accounting Research, 24(4), 1085-117

Cianci, A.M. \& Falsetta, D. (2008). Impact of investors' status on their evaluation of positive and negative, and past and future information. Accounting and Finance, 48, 719-739.

Deloitte. (2013). Risk Intelligent Proxy Disclosures - 2013 Trending Upward. Deloitte Development LLC. 1-12.

Dia, M. \& Zéghal, D. (2008). Fuzzy evaluation of risk management profiles disclosed in corporate annual reports. Canadian Journal of Administrative Sciences, 25, 237-254.

Advances in Accounting Behavioral Research, Vol 18 (2015): pg. 33-68. DOI. This article is @ Emerald (JAI Press) and permission has been granted for this version to appear in e-Publications@Marquette. Emerald (JAI Press) does not grant permission for this article to be further copied/distributed or hosted elsewhere without the express permission from Emerald (JAI Press). 
NOT THE PUBLISHED VERSION; this is the author's final, peer-reviewed manuscript. The published version may be accessed by following the link in the citation at the bottom of the page.

Dietrich, J., Kachelmeier, S., Kleinmuntz, D. \& Lismeier, T. (2001). Market efficiency, bounded rationality, and supplemental business reporting disclosures. Journal of Accounting Research, 39(2), 243-268.

Dobler, M. (2008). Incentive for risk reporting - A discretionary disclosure and cheap talk approach. The International Journal of Accounting, 43, 184-206.

Dobler, M., Lajili, K. \& Zéghal, D. (2011). Attributes of corporate risk disclosure: An international investigation in the manufacturing sector. Journal of International Accounting Research, 10(2), 184-206.

Financial Accounting Standard Board (FASB). (1975). Accounting for contingencies. Statement of Financial Accounting Standards No. 5. Norwalk, CT.: FASB.

Financial Accounting Standard Board. (1990). Employers' accounting for postretirement benefits other than pensions. Statement of Financial Accounting Standards No. 106. Norwalk, CT: FASB.

Financial Accounting Standard Board. (1997). Disclosures about segments of an enterprise and related information. Statement of Financial Accounting Standards No. 131. Norwalk, CT: FASB.

Financial Accounting Standard Board. (1998). Accounting for derivative instruments and hedging activities. Statement of Financial Accounting Standards No. 133. Norwalk, CT: FASB.

Financial Accounting Standard Board. (2000). Accounting for transfers and servicing of financial assets and extinguishments of liabilities. Statement of Financial Accounting Standards No. 140. Norwalk, CT: FASB.

Financial Accounting Standard Board. (2014). Disclosure framework. In the FASB's project update. Retrieved from http://www.fasb.org/jsp/FASB/FASBContent_C/ProjectUpdatePage\&cid $=1176156344894$

Finucane, M., Alhakami, A., Slovic, P. \& Johnson, S. M. (2000). The affect heuristic in judgments of risks and benefits. Journal of Behavioral Decision Making, 13, 1-17.

Fiske, S.T. (1980). Attention and weight in person perception: The impact of negative and extreme behavior. Journal of Experimental Research in Personality, 22, 889-906.

Fortin, A. \& Berthelot, S. (2012). Annual report risk disclosures and nonprofessional investors' judgments and decisions. Advances in Accounting Behavioral Research, 15, 1-28.

Frederickson, J. \& Miller, J. (2004). The effects of pro-forma earnings disclosures on analysts' and nonprofessional investors' equity valuation judgments. The Accounting Review, 79, 667-686.

Advances in Accounting Behavioral Research, Vol 18 (2015): pg. 33-68. DOI. This article is @ Emerald (JAI Press) and permission has been granted for this version to appear in e-Publications@Marquette. Emerald (JAI Press) does not grant permission for this article to be further copied/distributed or hosted elsewhere without the express permission from Emerald (JAI Press). 
Gates, S. (2006). Incorporating strategic risk into enterprise risk management: A survey of current corporate practice. Journal of Applied Corporate Finance, 18(4), 81-90.

Gendron, Y. and Bédard, J. (2006). On the constitution of audit committee effectiveness. Accounting, Organizations and Society, 31(3), 211-239.

Ghosh, D. \& Wu, A. (2012). The effect of positive and negative financial and non-financial performance measures on analysts' recommendations. Behavioral Research in Accounting, 24(2), 47-64.

Goldberg, L. \& Harsch, M. (2010). Enhanced disclosure in the Dow 30 and select financial companies: The role of the board in risk oversight. The Conference Board. August.

Hirst, D., Hopkins, P. \& Wahlen, J. (2004). Fair values, income measurement, and bank analysts' risk and valuation judgments. The Accounting Review, 79(2), 453-472.

Hodge, F. \& Pronk, M. (2006). The impact of expertise and investment familiarity on investors' use of online financial report information. Journal of Accounting, Auditing \& Finance, 21(3), 267-292.

Holt T. \& DeZoort, T. (2009). The effects of internal audit report disclosure on investor confidence and investment decisions. International Journal of Audit, 13, 61-77.

The Institute of Internal Auditors Research Foundation (IIARF). (2011). Improving Board Risk Oversight through Best Practices. The Institute of Internal Auditors Research Foundation, Florida: USA, 1-77.

Ikegami, T. (1993). Positive-negative asymmetry of priming effects on impression formation. European Journal of Social Psychology, 23, 116.

Ito, T. A., Larsen, J. T., Smith, N. K., \& Cacioppo, J. T. (1998). Negative information weighs more heavily on the brain: The negativity bias in evaluative categorizations. Journal of Personality and Social Psychology, 75, 887-900.

Kahneman, D. \& Tversky, A. (1984). Choices, values, and frames. American Psychologist, 39, 341-350.

Kirkpatrick, G. (2009). The corporate governance lessons from the financial crisis. Financial Market Trends - OECD, 1, 1-30.

Klinger, E., Barta, S. G., \& Maxeiner, M. E. (1980). Motivational correlates of thought content frequency and commitment. Journal of Personality and Social Psychology, 39, 1222-1237.

Koonce, L., McAnally, M. \& Mercer, M. (2005). How do investors judge the risk of financial items? The Accounting Review, 80(1), 221-241.

Lajili, K. \& Zéghal, D. (2005).A content analysis of risk management disclosures in Canadian annual reports. Canadian Journal of Administrative Sciences, 22(2), 125-142.

Advances in Accounting Behavioral Research, Vol 18 (2015): pg. 33-68. DOI. This article is @ Emerald (JAI Press) and permission has been granted for this version to appear in e-Publications@Marquette. Emerald (JAI Press) does not grant permission for this article to be further copied/distributed or hosted elsewhere without the express permission from Emerald (JAI Press). 
NOT THE PUBLISHED VERSION; this is the author's final, peer-reviewed manuscript. The published version may be accessed by following the link in the citation at the bottom of the page.

Lerner J. \& Keltner, D. (2000). Beyond valence: Toward a model of emotionspecific influences on judgment and choice. Cognition and Emotion, 14(4), 473-493.

Linsley, P. \& Shrives, P. (2006). Risk reporting: A study of risk disclosures in the annual reports of UK companies. The British Accounting Review, 38, 387-404.

Linsmeier, T. \& Pearson, N. (1997). Quantitative disclosures of market risk in the SEC release. Accounting Horizon, 11(1), 107-135.

Lipe, M. (1998). Individual investors' risk judgments and investment decisions: The impact of accounting and market data. Accounting, Organizations and Society, 23(7), 625-640.

Lipton, M., Neff, D., Brownstein, A., Rosenblum, S., Emmerich, A., Niles, S., \& Walker, B. (2010). Risk management and board of directors. The Corporate Governance Advisor, 18(2), 1-19.

Loewenstein, G. \& Lerner, J. (2003). The role of emotion in decision making. In R.J. Davidson, H.H. Goldsmith and K.R. Scherer (Eds.), Handbook of Affective Science (pp. 619-642). Oxford England: Oxford University Press.

Loewenstein, G.F., Weber, E.U., Hsee, C.K., and Welch, N. (2001). Risk as Feelings. Psychological Bulletin, 127(2), 267-286.

MacGregor, D. G., Slovic, P., \& Morgan, M. G. (1994). Perception of risks from electromagnetic fields: A psychometric evaluation of a riskcommunication approach. Risk Analysis, 14(5), 815-828.

Maletta, M. (1993). An examination of auditors' decisions to use internal auditors as assistants: The effect of inherent risk. Contemporary Accounting Research, 9(2), 508-525.

Maletta, M. \& T. Kida. (1993). The effect of risk factors on auditors' configural information processing. The Accounting Review, 68(3): 681-691.

Miller, J. S., \& Sedor, L. M. (2014). Do stock prices influence analysts' earnings forecasts? Behavioral Research in Accounting, 26(1), 85-108.

Nicholson, J. (2009). SEC Rules prompt greater board focus on risk. Faegre \& Benson. Retrieved from http://www.faegrebd.com/10742

Norman, C., Rose, J. \& Suh, I. (2011).The effects of disclosure type and audit committee expertise on Chief Audit Executives' tolerance for financial misstatements. Accounting, Organization, and Society, 36, 102-108.

Olsen, R. (1997). Investment risk: The experts' perspective. Financial Analysts Journal, 53(2), 62-66

Öhman, A., Lundqvist, D. \& Esteves, F. (2001). The face in the crowd revisited: A threat advantage with schematic stimuli. Journal of Personality and Social Psychology, 80, 381-396.

Pratto, F. \& John, O.P. (1991). Automatic vigilance: The attention-grabbing power of negative social information. Journal of Personality and Social Psychology, 61, 380-391.

Advances in Accounting Behavioral Research, Vol 18 (2015): pg. 33-68. DOI. This article is @ Emerald (JAI Press) and permission has been granted for this version to appear in e-Publications@Marquette. Emerald (JAI Press) does not grant permission for this article to be further copied/distributed or hosted elsewhere without the express permission from Emerald (JAI Press). 
NOT THE PUBLISHED VERSION; this is the author's final, peer-reviewed manuscript. The published version may be accessed by following the link in the citation at the bottom of the page.

Rajgopal, S. (1999). Early evidence on the informativeness of the SEC's market risk disclosures: The case of commodity price risk exposure of oil and gas producers. The Accounting Review, 74(3), 251-280.

Raber. R. (2003). The role of good corporate governance in overseeing risk. The Corporate Governance Advisor, 11(2), 11-16.

Rose, J. (2001). The effects of multimedia-induced affective states on recall and decision-making by individual investors. International Journal of Accounting Information Systems, 2, 22-40.

Schrand, C., \& Elliot, J. (1998). Risk and financial reporting: A summary of the discussion at the 1997 AAA/FASB conference. Accounting Horizons, 12(3), 271-282.

Securities and Exchange Commission (SEC). 1997. Disclosure of Accounting Policies for Derivative Financial Instruments, and Derivative Commodity Instruments and Disclosure of Quantitative and Qualitative Information about Market Risk Inherent in Derivative Financial Instruments, Other Financial Instruments, and Derivative Commodity Instruments. Release Nos. 33-7386; 34-38223; IC-22487; FR 48; International Series No. 1047; File No. 27-35-95. Washington, D.C.: SEC

Securities and Exchange Commission (SEC) (2000). Rethinking Disclosure in the Information Age: Can There Be Too Much of a Good Thing? Retrieved from http://www.sec.gov/news/speech/spch387.htm Securities and Exchange Commission (SEC) (2009). SEC Approves Enhanced Disclosure About Risk, Compensation and Corporate Governance. Retrieved from http://www.sec.gov/news/press/2009/2009-268.htm

Securities and Exchange Commission (SEC) (2014). Disclosure reform. In the SEC 2014: Comments of Mary Jo White. Retrieved from http://www.sec.gov/News/Speech/Detail/Speech/1370540677500\#.UPNw6Mo5jp.

Shadish, W.R., Cook T.D., \& Campbell D.T. (2002). Experimental and QuasiExperimental Designs for Generalized Causal Inference. Boston, MA: Houghton Mifflin.

Sharma, D. (2006). Effects of professional and non-professional investors' perceptions of board effectiveness on their judgments: An experimental study. Journal of Accounting and Public Policy, 25, 91115.

Slovic, P. (1987). Perception of Risk. Science, 236, 280-285.

Slovic, P. (1993). Perceived risk, trust, and democracy. Risk Analysis, 13(6), 675-682.

Slovic, P., Finucane, M., Peters, E., \& MacGregor, D. (2004). Risk as analysis and risk as feelings: Some thoughts about affect, reason, risk and rationality. Risk Analysis, 24(2), 1-11.

Advances in Accounting Behavioral Research, Vol 18 (2015): pg. 33-68. DOI. This article is @ Emerald (JAI Press) and permission has been granted for this version to appear in e-Publications@Marquette. Emerald (JAI Press) does not grant permission for this article to be further copied/distributed or hosted elsewhere without the express permission from Emerald (JAI Press). 
NOT THE PUBLISHED VERSION; this is the author's final, peer-reviewed manuscript. The published version may be accessed by following the link in the citation at the bottom of the page.

Smith, N.K., Cacioppo, J.T., Larsen, J.T., \& Chartrand, T.L. (2003). May I have your attention, please: Electrocortical responses to positive and negative stimuli. Neuropsychologia, 41, 171-183.

Su, H.J. \& Chang, C.J. (2010). The effect of corporate image as an affect heuristic on investors' decision making. Asia Pacific Management Review, 15(3), 453-476.

Taylor, S.E. (1991) Asymmetrical effects of positive and negative events: The mobilization-minimization hypothesis. Psychological Bulletin, 110, 6785.

Törngren, G. \& Montgomery, H. (2004). Worse than chance? Performance and confidence among professionals and laypeople in the stock market. Journal of Behavioral Finance, 5(3), 148-153.

Victoravich, L. (2010). Overly optimistic? Investor sophistication and the role of affective reactions to financial information in investors' stock price judgments. The Journal of Behavioral Finance, 11(1), 1-10.

Wilks, T.J. (2002). Predecisional distortion of evidence as a consequence of real-time audit review. The Accounting Review, 77(1), 51-71.

Advances in Accounting Behavioral Research, Vol 18 (2015): pg. 33-68. DOI. This article is @ Emerald (JAI Press) and permission has been granted for this version to appear in e-Publications@Marquette. Emerald (JAI Press) does not grant permission for this article to be further copied/distributed or hosted elsewhere without the express permission from Emerald (JAI Press). 
NOT THE PUBLISHED VERSION; this is the author's final, peer-reviewed manuscript. The published version may be accessed by following the link in the citation at the bottom of the page.

Figure 1. Nomological Map of the Research Model.

Theoretical Level

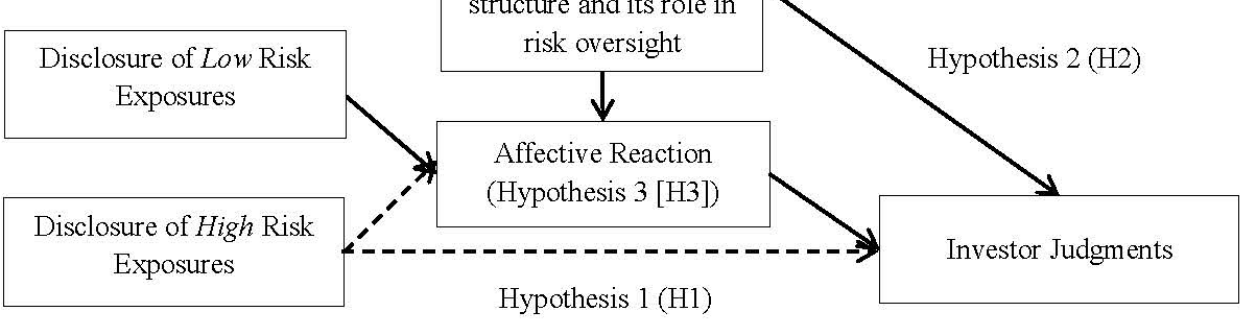

Operational Level

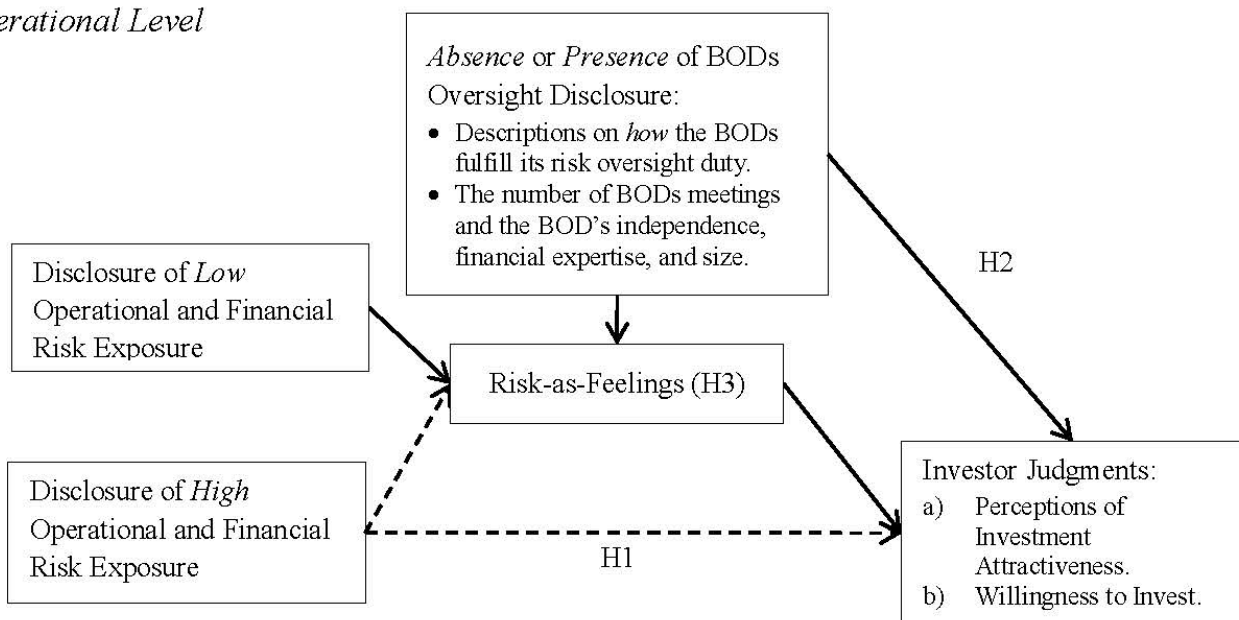

Figure 2. The Effects of Risk Disclosure and BODs Oversight Disclosure on Investor Judgments

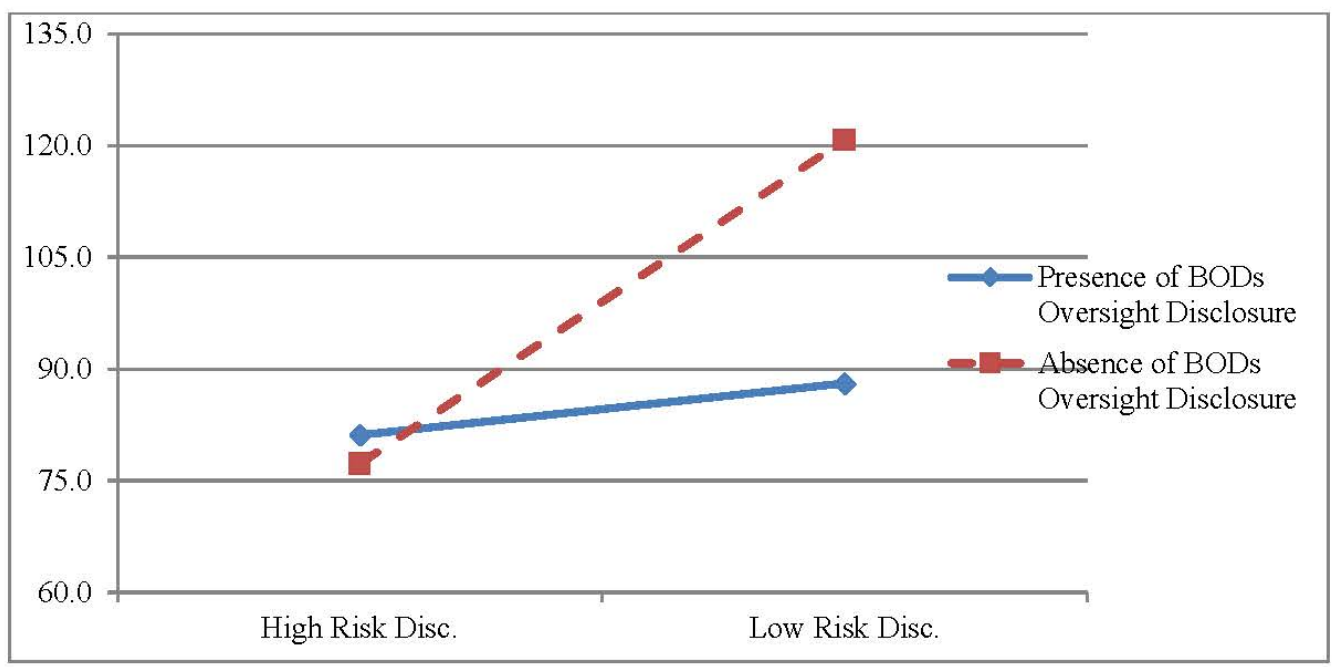

Advances in Accounting Behavioral Research, Vol 18 (2015): pg. 33-68. DOI. This article is (C) Emerald (JAI Press) and permission has been granted for this version to appear in e-Publications@Marquette. Emerald (JAI Press) does not grant permission for this article to be further copied/distributed or hosted elsewhere without the express permission from Emerald (JAI Press). 
NOT THE PUBLISHED VERSION; this is the author's final, peer-reviewed manuscript. The published version may be accessed by following the link in the citation at the bottom of the page.

Figure 3. Risk-as-Feelings Mediating the Impact of BODs Oversight Disclosure on Investor Judgments in Low Risk Disclosure Condition

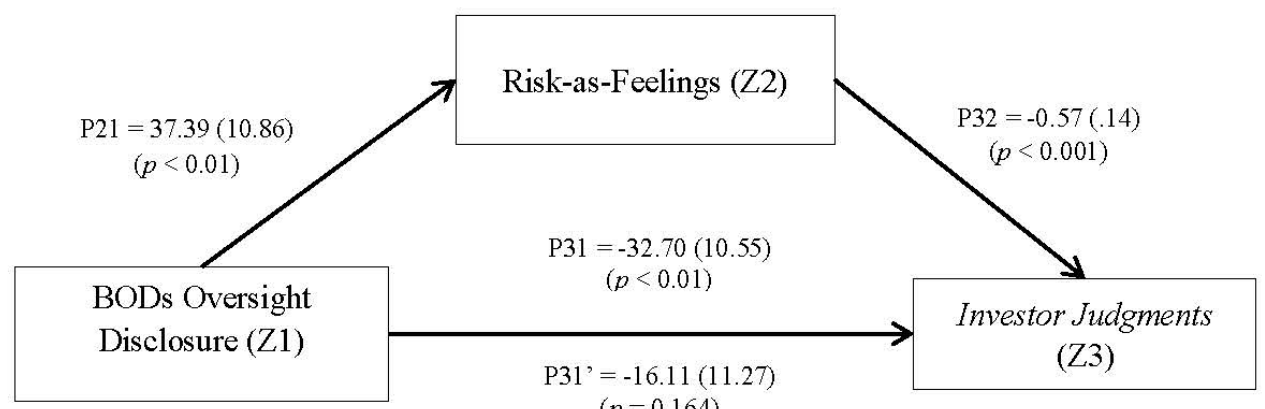

* Unstandardized Regression Coefficient (Std. Error)

Table 1. Demographic Information across Treatment Conditions

\begin{tabular}{|c|c|c|c|c|c|c|}
\hline & $\begin{array}{c}\text { Low } \\
\text { Risk/No } \\
\text { Oversight } \\
(\mathrm{N}=17)\end{array}$ & $\begin{array}{c}\text { Low } \\
\text { Risk/ } \\
\text { Oversight } \\
(\mathrm{N}=15)\end{array}$ & $\begin{array}{c}\text { High } \\
\text { Risk/No } \\
\text { Oversight } \\
(\mathrm{N}=15)\end{array}$ & $\begin{array}{c}\text { High } \\
\text { Risk/ } \\
\text { Oversight } \\
(\mathrm{N}=15)\end{array}$ & $\begin{array}{c}\text { Overall } \\
(\mathrm{N}=62)\end{array}$ & $\begin{array}{l}\text { Overall } \\
\text { Group } \\
\text { Diff. }\end{array}$ \\
\hline Gender $^{(a)}$ & $\begin{array}{l}11 \\
(6) \\
\end{array}$ & $\begin{array}{l}12 \\
(3) \\
\end{array}$ & $\begin{array}{c}8 \\
(7) \\
\end{array}$ & $\begin{array}{l}10 \\
(5)\end{array}$ & $\begin{array}{c}41 \\
(21) \\
\end{array}$ & $p>0.05^{(\mathrm{c})}$ \\
\hline $\begin{array}{l}\text { Type of Employer } \\
\text { Investment Bank } \\
\text { Commercial } \\
\text { Bank/Trust } \\
\text { Brokerage Firm } \\
\text { Accounting Firm } \\
\text { Other Corporation }\end{array}$ & $\begin{array}{l}5 \\
4 \\
\\
5 \\
0 \\
3\end{array}$ & $\begin{array}{l}4 \\
3 \\
\\
3 \\
1 \\
4\end{array}$ & $\begin{array}{l}5 \\
5 \\
1 \\
1 \\
3\end{array}$ & $\begin{array}{l}3 \\
5 \\
4 \\
2 \\
1\end{array}$ & $\begin{array}{c}17 \\
17 \\
\\
13 \\
4 \\
11\end{array}$ & $p>0.05^{(\mathrm{c})}$ \\
\hline $\begin{array}{l}\text { Years of experience in } \\
\text { investment }^{(b)}\end{array}$ & $\begin{array}{l}11.29 \\
(5.60)\end{array}$ & $\begin{array}{l}12.13 \\
(3.23)\end{array}$ & $\begin{array}{l}13.13 \\
(5.66)\end{array}$ & $\begin{array}{l}12.20 \\
(3.05)\end{array}$ & $\begin{array}{l}12.16 \\
(4.52)\end{array}$ & $p>0.05^{(\mathrm{d})}$ \\
\hline $\begin{array}{l}\text { Undergraduate Major } \\
\text { Finance } \\
\text { Accounting } \\
\text { Accounting/Finance } \\
\text { Business Admin. } \\
\text { Other }\end{array}$ & $\begin{array}{c}10 \\
1 \\
0 \\
6 \\
0\end{array}$ & $\begin{array}{l}7 \\
1 \\
0 \\
4 \\
3\end{array}$ & $\begin{array}{l}8 \\
3 \\
0 \\
2 \\
2\end{array}$ & $\begin{array}{l}7 \\
3 \\
2 \\
0 \\
3\end{array}$ & $\begin{array}{c}32 \\
8 \\
2 \\
12 \\
8\end{array}$ & $p>0.05^{(\mathrm{c})}$ \\
\hline $\begin{array}{l}\text { Graduate Major } \\
\text { MBA } \\
\text { Macc } \\
\text { JD } \\
\text { N/A }\end{array}$ & $\begin{array}{c}12 \\
0 \\
1 \\
4\end{array}$ & $\begin{array}{l}9 \\
1 \\
1 \\
4\end{array}$ & $\begin{array}{l}5 \\
0 \\
1 \\
9\end{array}$ & $\begin{array}{l}6 \\
2 \\
0 \\
7\end{array}$ & $\begin{array}{c}32 \\
3 \\
3 \\
24\end{array}$ & $p>0.05^{(\mathrm{c})}$ \\
\hline
\end{tabular}

\footnotetext{
(a) Male (Female)

(b) Mean (s.d.)

(c) Significance of the Chi-Square test

(d) ANOVA mean difference across treatment groups
}

Advances in Accounting Behavioral Research, Vol 18 (2015): pg. 33-68. DOI. This article is C) Emerald (JAI Press) and permission has been granted for this version to appear in e-Publications@Marquette. Emerald (JAI Press) does not grant permission for this article to be further copied/distributed or hosted elsewhere without the express permission from Emerald (JAI Press). 
NOT THE PUBLISHED VERSION; this is the author's final, peer-reviewed manuscript. The published version may be accessed by following the link in the citation at the bottom of the page.

Table 2. Experimental Procedures

\begin{tabular}{|c|c|c|c|c|}
\hline \multirow[b]{2}{*}{$\begin{array}{c}\text { Sequence of the Case Material } \\
\text { Distributed }\end{array}$} & \multicolumn{2}{|c|}{$\begin{array}{l}\text { Absence of BODs oversight } \\
\text { disclosure }\end{array}$} & \multicolumn{2}{|c|}{$\begin{array}{c}\text { Presence of BODs oversight } \\
\text { disclosure }\end{array}$} \\
\hline & $\begin{array}{l}\text { Disclosure on } \\
\text { High } \\
\text { Risk Exposure } \\
\text { Condition }\end{array}$ & $\begin{array}{l}\text { Disclosure on } \\
\text { Low } \\
\text { Risk Exposure } \\
\text { Condition }\end{array}$ & $\begin{array}{l}\text { Disclosure on } \\
\text { High } \\
\text { Risk Exposure } \\
\text { Condition }\end{array}$ & $\begin{array}{l}\text { Disclosure on } \\
\text { Low } \\
\text { Risk Exposure } \\
\text { Condition }\end{array}$ \\
\hline Hypothetical company's profile. & $\mathrm{X}$ & $\mathrm{X}$ & $\mathrm{X}$ & $\mathrm{X}$ \\
\hline $\begin{array}{l}\text { A three-year summary on the } \\
\text { hypothetical financial information. }\end{array}$ & $\mathrm{X}$ & $\mathrm{X}$ & $\mathrm{X}$ & $\mathrm{X}$ \\
\hline $\begin{array}{l}\text { Disclosure on operational risk and } \\
\text { financial risk (see Appendix A). }\end{array}$ & $\begin{array}{c}\text { High risk } \\
\text { manipulation }\end{array}$ & $\begin{array}{c}\text { Low risk } \\
\text { manipulation }\end{array}$ & $\begin{array}{c}\text { High risk } \\
\text { manipulation }\end{array}$ & $\begin{array}{c}\text { Low risk } \\
\text { manipulation }\end{array}$ \\
\hline Disclosure on other risks. & $\mathrm{X}$ & $\mathrm{X}$ & $\mathrm{X}$ & $\mathrm{X}$ \\
\hline $\begin{array}{l}\text { Disclosure on BODs oversight (see } \\
\text { Appendix B). }\end{array}$ & Not presented & Not presented & Presented & Presented \\
\hline $\begin{array}{l}\text { Participants assess the hypothetical } \\
\text { company's risk exposure including } \\
\text { items measuring Risk-as-Feelings. }\end{array}$ & $\mathrm{X}$ & $\mathrm{X}$ & $\mathrm{X}$ & $\mathrm{X}$ \\
\hline $\begin{array}{l}\text { A five-year summary concerning the } \\
\text { hypothetical firm's financial ratios and } \\
\text { historical stock return and volatility } \\
\text { compared to the S\&P } 500 \text { return and } \\
\text { its volatility. }\end{array}$ & $\mathrm{X}$ & $\mathrm{X}$ & $\mathrm{X}$ & $\mathrm{X}$ \\
\hline $\begin{array}{l}\text { Participants indicate their investment } \\
\text { judgments. }\end{array}$ & $\mathrm{X}$ & $\mathrm{X}$ & $\mathrm{X}$ & $\mathrm{X}$ \\
\hline $\begin{array}{l}\text { Demographic questions, manipulation } \\
\text { check items and a number of } \\
\text { debriefing items. }\end{array}$ & $\mathrm{X}$ & $\mathrm{X}$ & $\mathrm{X}$ & $\mathrm{X}$ \\
\hline
\end{tabular}

$\mathrm{X}=$ Same material distributed across treatment condition

Advances in Accounting Behavioral Research, Vol 18 (2015): pg. 33-68. DOI. This article is @ Emerald (JAI Press) and permission has been granted for this version to appear in e-Publications@Marquette. Emerald (JAI Press) does not grant permission for this article to be further copied/distributed or hosted elsewhere without the express permission from Emerald (JAI Press). 
NOT THE PUBLISHED VERSION; this is the author's final, peer-reviewed manuscript. The published version may be accessed by following the link in the citation at the bottom of the page.

Table 3. Final Factor Loadings for the Items Retained in the Principle Components Analysis of the Risk Assessment Measures

\begin{tabular}{|l|ccc|}
\hline \multicolumn{1}{|c|}{ Items } & \multicolumn{3}{c|}{ Adjusted Factor Loadings } \\
& Factor 1 & Factor 2 & Factor 3 \\
\hline Loss Probability & 0.848 & -0.123 & -0.073 \\
Loss Outcome & 0.735 & 0.307 & 0.157 \\
Gain Probability & 0.753 & 0.156 & -0.239 \\
Gain Outcome & 0.683 & 0.192 & -0.348 \\
Worry & 0.461 & 0.736 & 0.246 \\
Catastrophic & 0.192 & 0.915 & 0.200 \\
Newness & -0.065 & 0.855 & 0.203 \\
Control & -0.134 & 0.270 & 0.920 \\
Participant Know & -0.097 & 0.285 & 0.831 \\
Management Know & -0.076 & 0.065 & 0.884 \\
\hline
\end{tabular}

Notes:

This table reports the factor patterns obtained from a principal component analysis with a VARIMAX rotation, using participants' responses to the 11 items utilized by Koonce et al. (2005). Italicized numbers indicate the largest factor loading for a particular item. Cronbach's Alpha for Factor 1 is 0.799 , Factor 2 is 0.825 , and Factor 3 is 0.790 . See below for a description of the 11-items:

- Loss Probability: What do you think is the probability of an economic loss to SW, Inc. from the risk exposures disclosed in the previous section? $(0=$ zero probability; $100=$ certainty $)$

- Loss Outcome: If there were an economic loss to SW from the risk exposures disclosed in the previous section, how large a loss would you expect? ( $0=$ zero loss; $100=$ very large loss $)$

- Gain Probability: What do you think is the probability of an economic gain to SW, Inc. from the risk exposures disclosed in the previous section? ( $0=$ zero probability; $100=$ certainty $)$

- Gain Outcome: If there were an economic gain to SW from the risk exposures disclosed in the previous section, how large a gain would you expect? ( $0=$ zero gain; $100=$ very large gain)

- Worry: Do the risk exposures disclosed in the previous section cause you to worry or not? ( $0=$ no worry; $100=$ high worry)

- Catastrophic: To what extent are the risk exposures disclosed in the previous section likely to be catastrophic? $(0=$ not likely to be catastrophic; $100=$ likely to be catastrophic)

- Newness: Are the risk exposures disclosed in the previous section new, old, or familiar ones? $(0=$ old; $100=$ new $)$

- Control: How difficult is it for SW, Inc. management to use its skill and diligence to limit (or control) the risk exposures disclosed in the previous section? $(0=$ very difficult to limit (or control); $100=$ very easy to limit (or control)

- Participant Know: To what extent are the risk exposures disclosed in the previous section known precisely by you? $(0=$ not known; $100=$ known precisely $)$

- Management Know: To what extent are the risk exposures disclosed in the previous section known precisely by SW's management? ( $0=$ not known; 100=known precisely)

Advances in Accounting Behavioral Research, Vol 18 (2015): pg. 33-68. DOI. This article is @ Emerald (JAI Press) and permission has been granted for this version to appear in e-Publications@Marquette. Emerald (JAI Press) does not grant permission for this article to be further copied/distributed or hosted elsewhere without the express permission from Emerald (JAI Press). 
NOT THE PUBLISHED VERSION; this is the author's final, peer-reviewed manuscript. The published version may be accessed by following the link in the citation at the bottom of the page.

Table 4. Summary of the Main Variables and Measures

\begin{tabular}{|c|c|c|c|}
\hline & Variable & Facet(s) Measured & Measurement Source \\
\hline \multirow{2}{*}{$\begin{array}{l}\text { Independent } \\
\text { Variables }\end{array}$} & Risk Disclosure & (1) High (0) Low & See Appendix A \\
\hline & $\begin{array}{l}\text { BODs Oversight } \\
\text { Disclosure }\end{array}$ & (1) Presence (0) Absence & See Appendix B \\
\hline \multirow[t]{4}{*}{$\begin{array}{l}\text { Mediating } \\
\text { Variables }\end{array}$} & Risk-As-Analysis & $\begin{array}{l}\text { LossOutcome } \\
\text { LossProbability } \\
\text { GainOutcome } \\
\text { GainProbability }\end{array}$ & $\begin{array}{l}\text { Koonce }(2005) \\
\text { Sum of } 4 \text { Items, ranging from } 0 \text { (no } \\
\text { risk) to } 400 \text { (high risk). } \\
\text { Cronbach's alpha }=0.799\end{array}$ \\
\hline & Risk-As-Control & $\begin{array}{l}\text { ParticipantKnown } \\
\text { ManagementKnown } \\
\text { Control }\end{array}$ & $\begin{array}{l}\text { Koonce (2005) } \\
\text { Sum of } 3 \text { Items, ranging from } 0 \text { (no } \\
\text { risk) to } 300 \text { (high risk). } \\
\text { Cronbach's alpha }=0.825\end{array}$ \\
\hline & Risk-As-Feelings & $\begin{array}{l}\text { Worry } \\
\text { Catastrophic } \\
\text { Newness }\end{array}$ & $\begin{array}{l}\text { Koonce (2005) } \\
\text { Sum of } 3 \text { Items, ranging from } 0 \text { (no } \\
\text { risk) to } 300 \text { (high risk). } \\
\text { Cronbach's alpha }=0.790\end{array}$ \\
\hline & Overall Risk & $\begin{array}{l}\text { Overall, how risky are the risk } \\
\text { exposures disclosed in the } \\
\text { previous section to SW, Inc.? }\end{array}$ & $\begin{array}{l}\text { Newly Created } \\
1 \text { Item } \\
\text { (0) No Risk } \\
\text { (100) High Risk }\end{array}$ \\
\hline \multirow[t]{3}{*}{$\begin{array}{l}\text { Dependent } \\
\text { Variables }\end{array}$} & Attractiveness & $\begin{array}{l}\text { How attractive is the stock of } \\
\text { SW, Inc. as an investment } \\
\text { opportunity? }\end{array}$ & $\begin{array}{l}\text { Newly Created } \\
1 \text { Item } \\
\text { (0) Not Attractive } \\
\text { (100) Highly Attractive }\end{array}$ \\
\hline & Investment & $\begin{array}{l}\text { How likely would you be to } \\
\text { invest in SW's stock? }\end{array}$ & $\begin{array}{l}\text { Newly Created } \\
1 \text { Item } \\
\text { (0) Not at all Likely } \\
\text { (100) Extremely Likely }\end{array}$ \\
\hline & Investor Judgments & $\begin{array}{l}\text { Sum of Attractiveness and } \\
\text { Investment }\end{array}$ & $\begin{array}{l}\text { Cronbach's Alpha (reliability statistics) } \\
\text { of the combined measure }=0.923 .\end{array}$ \\
\hline
\end{tabular}

Advances in Accounting Behavioral Research, Vol 18 (2015): pg. 33-68. DOI. This article is @ Emerald (JAI Press) and permission has been granted for this version to appear in e-Publications@Marquette. Emerald (JAI Press) does not grant permission for this article to be further copied/distributed or hosted elsewhere without the express permission from Emerald (JAI Press). 
NOT THE PUBLISHED VERSION; this is the author's final, peer-reviewed manuscript. The published version may be accessed by following the link in the citation at the bottom of the page.

Table 5. Descriptive Statistics Across Treatment Conditions: Mean (s.d.)

\begin{tabular}{|c|c|c|c|c|c|c|c|}
\hline & \multicolumn{6}{|c|}{ Treatment Conditions } & \multirow[b]{2}{*}{$\begin{array}{l}\text { Group Diff. } \\
\text { (All } 4 \\
\text { treatments) }\end{array}$} \\
\hline & $\begin{array}{c}\text { Low Risk/ } \\
\text { No BODs } \\
\text { Oversight } \\
\text { Disclosure }\end{array}$ & $\begin{array}{c}\text { Low Risk/ } \\
\text { BODs } \\
\text { Oversight } \\
\text { Disclosure }\end{array}$ & $\begin{array}{c}\text { Low Risk } \\
\text { Overall }\end{array}$ & $\begin{array}{c}\text { High Risk/ } \\
\text { No BODs } \\
\text { Oversight } \\
\text { Disclosure }\end{array}$ & $\begin{array}{c}\text { High Risk/ } \\
\text { BODs } \\
\text { Oversight } \\
\text { Disclosure }\end{array}$ & $\begin{array}{c}\text { High Risk } \\
\text { Overall }\end{array}$ & \\
\hline Risk-as-Analys is ${ }^{(b)},(c)$ & $\begin{array}{l}154.4 \\
(43.6)\end{array}$ & $\begin{array}{r}132.6 \\
(28.2)\end{array}$ & $\begin{array}{l}144.2 \\
(38.3)\end{array}$ & $\begin{array}{l}189.5 \\
(34.0)\end{array}$ & $\begin{array}{r}194.7 \\
(54.4)\end{array}$ & $\begin{array}{l}192.1 \\
(44.6)\end{array}$ & $p<0.01$ \\
\hline Risk-as-Feelings ${ }^{(b)}$ & $\begin{array}{c}83.9 \\
(23.1)\end{array}$ & $\begin{array}{l}121.3 \\
(37.5)\end{array}$ & $\begin{array}{l}101.5 \\
(35.6)\end{array}$ & $\begin{array}{l}178.5 \\
(47.8)\end{array}$ & $\begin{array}{l}169.3 \\
(39.9)\end{array}$ & $\begin{array}{l}173.9 \\
(43.5)\end{array}$ & $p<0.01$ \\
\hline Risk-as-Control $^{\text {(b) (d) }}$ & $\begin{array}{l}142.5 \\
(19.9)\end{array}$ & $\begin{array}{l}176.4 \\
(55.1)\end{array}$ & $\begin{array}{l}158.4 \\
(43.2)\end{array}$ & $\begin{array}{l}174.5 \\
(61.4)\end{array}$ & $\begin{array}{l}173.3 \\
(15.8)\end{array}$ & $\begin{array}{l}173.9 \\
(44.1)\end{array}$ & $p<0.10$ \\
\hline Overall Risk & $\begin{array}{c}44.1 \\
(12.5)\end{array}$ & $\begin{array}{c}50.5 \\
(11.4)\end{array}$ & $\begin{array}{c}47.1 \\
(12.3)\end{array}$ & $\begin{array}{c}64.6 \\
(10.6)\end{array}$ & $\begin{array}{c}59.1 \\
(14.9)\end{array}$ & $\begin{array}{c}61.8 \\
(13.0)\end{array}$ & $p<0.10$ \\
\hline Attractiveness & $\begin{array}{c}59.7 \\
(19.6)\end{array}$ & $\begin{array}{c}45.4 \\
(11.1)\end{array}$ & $\begin{array}{c}53.0 \\
(15.6)\end{array}$ & $\begin{array}{c}39.7 \\
(14.5)\end{array}$ & $\begin{array}{l}39.5 \\
(9.2)\end{array}$ & $\begin{array}{c}39.6 \\
(11.9)\end{array}$ & $p<0.05$ \\
\hline Investment & $\begin{array}{c}61.1 \\
(18.8)\end{array}$ & $\begin{array}{c}42.7 \\
(12.4)\end{array}$ & $\begin{array}{c}52.4 \\
(18.4)\end{array}$ & $\begin{array}{c}37.5 \\
(18.7)\end{array}$ & $\begin{array}{c}41.6 \\
(12.3)\end{array}$ & $\begin{array}{c}39.6 \\
(15.7)\end{array}$ & $p<0.01$ \\
\hline Investor Judgments & $\begin{array}{l}120.8 \\
(34.7)\end{array}$ & $\begin{array}{c}88.1 \\
(22.8)\end{array}$ & $\begin{array}{l}105.4 \\
(33.7)\end{array}$ & $\begin{array}{c}77.2 \\
(31.0)\end{array}$ & $\begin{array}{c}81.1 \\
(19.5)\end{array}$ & $\begin{array}{c}79.2 \\
(25.5)\end{array}$ & $p<0.01$ \\
\hline
\end{tabular}

(a) ANOVA mean difference across treatment groups

(b) Items from Koonce (2005) are used as alternate measures of risk. A principle components analysis elicited a three factor solution

(all item loadings for each factor are $>0.60$ ). The three factors are titled: Risk-as-Analysis, Risk-as-Feelings, and Risk-as-Control.

(c) Results of Tukey's HSD test procedure indicate that the mean of Risk-as-Analysis does not differ significantly between the absence of BODs Oversight Disclosure condition and the presence of BODs Oversight Disclosure condition, under the high ( $p=$ $0.986)$ or low $(p=0.453)$ risk disclosure condition.

(d) Results of Tukey's HSD test procedure indicate that the mean of Risk-as-Control does not differ significantly between the absence of BODs Oversight Disclosure condition and the presence of BODs Oversight Disclosure condition, under the high ( $p=$ $1.000)$ or low $(p=0.124)$ risk disclosure condition.

\author{
Risk-as-Analysis $=$ Loss probability, loss outcome, gain probability \& gain outcome. \\ Risk-as-Feelings $=$ Worry, catastrophic, \& newness. \\ Risk-as-Control $=$ Control, participant know \& management know \\ Overall_Risk $=$ Overall, how risky are the risk exposures disclosed in the previous section to SW, Inc.? \\ $(0=$ no risk; $100=$ high risk $)$ \\ Attractiveness $=$ How attractive is the stock of SW, Inc. as an investment opportunity? \\ $(0=$ not attractive; $100=$ highly attractive) \\ Investment $=$ How likely would you invest in SW stock? \\ $(0=$ not at all likely, $100=$ extremely likely $)$ \\ Investor Judgments $=$ A combined measure of Attractiveness and Investment. \\ - Attractiveness: How attractive is the stock of SW, Inc. as an investment \\ opportunity? \\ - Investment: How likely would you invest in SW stock?
}

Advances in Accounting Behavioral Research, Vol 18 (2015): pg. 33-68. DOI. This article is C) Emerald (JAI Press) and permission has been granted for this version to appear in e-Publications@Marquette. Emerald (JAI Press) does not grant permission for this article to be further copied/distributed or hosted elsewhere without the express permission from Emerald (JAI Press). 
NOT THE PUBLISHED VERSION; this is the author's final, peer-reviewed manuscript. The published version may be accessed by following the link in the citation at the bottom of the page.

Table 6. Correlation Matrix

\begin{tabular}{|c|c|c|c|c|c|c|c|c|c|c|}
\hline & & $\begin{array}{l}\text { Risk } \\
\text { Disclo- } \\
\text { sure }\end{array}$ & $\begin{array}{c}\text { BODs } \\
\text { Oversight } \\
\text { Disclosure }\end{array}$ & $\begin{array}{l}\text { Attracti- } \\
\text { veness }\end{array}$ & Investment & $\begin{array}{l}\text { Overall } \\
\text { _Risk }\end{array}$ & $\begin{array}{l}\text { Investor } \\
\text { Judgments }\end{array}$ & $\begin{array}{l}\text { Risk-as- } \\
\text { Analysis }\end{array}$ & $\begin{array}{l}\text { Risk-as- } \\
\text { Feelings }\end{array}$ & $\begin{array}{l}\text { Risk-as- } \\
\text { Control }\end{array}$ \\
\hline $\begin{array}{l}\text { Risk } \\
\text { Disclosure }\end{array}$ & $\begin{array}{l}\text { Pearson Corr. } \\
\text { Sig. (2-tailed) }\end{array}$ & 1 & & & & & & & & \\
\hline $\begin{array}{l}\text { BODs } \\
\text { Oversight } \\
\text { Disclosure }\end{array}$ & $\begin{array}{l}\text { Pearson Corr. } \\
\text { Sig. (2-tailed) }\end{array}$ & $\begin{array}{l}0.031 \\
0.809\end{array}$ & 1 & & & & & & & \\
\hline $\begin{array}{l}\text { Attracti- } \\
\text { veness }\end{array}$ & $\begin{array}{l}\text { Pearson Corr. } \\
\text { Sig. (2-tailed) }\end{array}$ & $\begin{array}{l}-0.434^{* * *} \\
<0.001\end{array}$ & $\begin{array}{c}-0.256^{*} \\
0.045\end{array}$ & 1 & & & & & & \\
\hline Investment & $\begin{array}{l}\text { Pearson Corr. } \\
\text { Sig. (2-tailed) }\end{array}$ & $\begin{array}{c}-0.356^{* * *} \\
0.004\end{array}$ & $\begin{array}{c}-0.219 \\
0.088\end{array}$ & $\begin{array}{l}0.867^{\text {*** }} \\
<0.001\end{array}$ & 1 & & & & & \\
\hline $\begin{array}{l}\text { Overall } \\
\text { Risk }\end{array}$ & $\begin{array}{l}\text { Pearson Corr. } \\
\text { Sig. (2-tailed) }\end{array}$ & $\begin{array}{l}0.509^{* * *} \\
<0.001\end{array}$ & $\begin{array}{l}0.037 \\
0.733\end{array}$ & $\begin{array}{c}-0.282^{*} \\
0.026\end{array}$ & $\begin{array}{c}-0.333^{* * *} \\
0.008\end{array}$ & 1 & & & & \\
\hline $\begin{array}{l}\text { Investor } \\
\text { Judgments }\end{array}$ & $\begin{array}{l}\text { Pearson Corr. } \\
\text { Sig. (2-tailed) }\end{array}$ & $\begin{array}{c}-0.406^{* * *} \\
0.001\end{array}$ & $\begin{array}{l}-0.244 \\
0.056\end{array}$ & $\begin{array}{c}0.961^{* * *} \\
0.000\end{array}$ & $\begin{array}{c}0.972^{* * *} \\
0.000\end{array}$ & $\begin{array}{c}-0.320^{*} \\
0.011\end{array}$ & 1 & & & \\
\hline $\begin{array}{l}\text { Risk-as- } \\
\text { Analysis }\end{array}$ & $\begin{array}{l}\text { Pearson Corr. } \\
\text { Sig. (2-tailed) }\end{array}$ & $\begin{array}{l}0.507^{* * *} \\
<0.001\end{array}$ & $\begin{array}{l}-0.076 \\
0.558\end{array}$ & $\begin{array}{c}-0.287^{*} \\
0.024\end{array}$ & $\begin{array}{c}-0.188 \\
0.144\end{array}$ & $\begin{array}{l}0.440^{\text {** }} \\
<0.001\end{array}$ & $\begin{array}{c}-0.241 \\
0.059\end{array}$ & 1 & & \\
\hline $\begin{array}{l}\text { Risk-as- } \\
\text { Feelings }\end{array}$ & $\begin{array}{l}\text { Pearson Corr. } \\
\text { Sig. (2-tailed) }\end{array}$ & $\begin{array}{l}0.680^{* * *} \\
<0.001\end{array}$ & $\begin{array}{l}0.160 \\
0.215\end{array}$ & $\begin{array}{l}-0.453^{* * *} \\
<0.001\end{array}$ & $\begin{array}{c}-0.349^{* * *} \\
0.005\end{array}$ & $\begin{array}{l}0.497^{\text {**k }} \\
<0.001\end{array}$ & $\begin{array}{c}-0.410^{* * *} \\
0.001\end{array}$ & $\begin{array}{l}0.294^{*} \\
0.020\end{array}$ & 1 & \\
\hline $\begin{array}{l}\text { Risk-as- } \\
\text { Control }\end{array}$ & $\begin{array}{l}\text { Pearson Corr. } \\
\text { Sig. (2-tailed) }\end{array}$ & $\begin{array}{l}0.177 \\
0.168\end{array}$ & $\begin{array}{l}0.198 \\
0.123\end{array}$ & $\begin{array}{r}-0.209 \\
0.104\end{array}$ & $\begin{array}{c}-0.083 \\
0.523\end{array}$ & $\begin{array}{l}0.149 \\
0.247\end{array}$ & $\begin{array}{c}-0.146 \\
0.259\end{array}$ & $\begin{array}{c}-0.191 \\
0.136\end{array}$ & $\begin{array}{l}0.413^{*-k} \\
<0.001\end{array}$ & 1 \\
\hline $\begin{array}{l}\text { Years of } \\
\text { Investment } \\
\text { Experience }\end{array}$ & $\begin{array}{l}\text { Pearson Corr. } \\
\text { Sig. (2-tailed) }\end{array}$ & $\begin{array}{l}0.109 \\
0.398\end{array}$ & $\begin{array}{l}0.001 \\
0.993\end{array}$ & $\begin{array}{c}-0.068 \\
0.600\end{array}$ & $\begin{array}{l}-0.068 \\
0.599\end{array}$ & $\begin{array}{l}0.073 \\
0.572\end{array}$ & $\begin{array}{l}-0.070 \\
0.587\end{array}$ & $\begin{array}{l}0.099 \\
0.442\end{array}$ & $\begin{array}{l}0.150 \\
0.244\end{array}$ & $\begin{array}{l}0.064 \\
0.623\end{array}$ \\
\hline
\end{tabular}

(*) Correlation is significant at the 0.05 level (2-tailed).

(**) Correlation is significant at the 0.10 level (2-tailed).

(a) $\mathrm{N}=62$

\begin{tabular}{|c|c|}
\hline Risk Disclosure $=$ & Disclosure on high or low level of operational and financial risk exposure. \\
\hline BODs Oversight Disclosure $(\mathrm{BOD})=$ & Absence or presence of BODs oversight disclosure. \\
\hline Attractiveness $=$ & $\begin{array}{l}\text { How attractive is the stock of SW, Inc. as an investment opportunity? } \\
(0=\text { not attractive; } 100=\text { highly attractive })\end{array}$ \\
\hline Investment $=$ & $\begin{array}{l}\text { How likely would you invest in SW stock? } \\
(0=\text { not at all likely; } 100=\text { extremely likely })\end{array}$ \\
\hline Overall_Risk $=$ & $\begin{array}{l}\text { Overall, how risky are the risk exposures disclosed in the previous section to SW, Inc.? } \\
\text { ( } 0 \text { =no risk; } 100=\text { high risk) }\end{array}$ \\
\hline Investor Judgments $=$ & $\begin{array}{l}\text { A combined measure of Attractiveness and Investment. } \\
\text { - Attractiveness: How attractive is the stock of SW, Inc. as an investment } \\
\text { opportunity? } \\
\text { - Investment: How likely would you invest in SW stock? }\end{array}$ \\
\hline Risk-as-Analysis $=$ & Loss probability, loss outcome, gain probability \& gain outcome. \\
\hline Risk-as-Feelings $=$ & Worry, catastrophic, \& newness. \\
\hline Risk-as-Control $=$ & Control, participant know \& management know \\
\hline ars of Investment Experience $=$ & Years of experience in equity valuation and investment recommendation/decisions \\
\hline
\end{tabular}

Advances in Accounting Behavioral Research, Vol 18 (2015): pg. 33-68. DOI. This article is @ Emerald (JAI Press) and permission has been granted for this version to appear in e-Publications@Marquette. Emerald (JAI Press) does not grant permission for this article to be further copied/distributed or hosted elsewhere without the express permission from Emerald (JAI Press). 
NOT THE PUBLISHED VERSION; this is the author's final, peer-reviewed manuscript. The published version may be accessed by following the link in the citation at the bottom of the page.

Table 7. ANOVA Results for DV = Investor Judgments

\begin{tabular}{|c|c|c|c|c|}
\hline \multicolumn{5}{|c|}{ Panel A: Mean (standard deviation) \{sample size $\}$ across treatment conditions } \\
\hline & & \multicolumn{2}{|c|}{ Risk Disclosure } & \multirow{2}{*}{$\begin{array}{c}\text { Main Effect: } \\
\text { BODs Oversight } \\
\text { Disclosure }\end{array}$} \\
\hline & & High & Low & \\
\hline \multirow{6}{*}{$\begin{array}{c}\text { BODs } \\
\text { Oversight } \\
\text { Disclosure }\end{array}$} & Presence & 81.13 & 88.07 & 84.60 \\
\hline & & $(19.53)$ & $(22.78)$ & $(21.15)$ \\
\hline & & $\{15\}$ & $\{15\}$ & $\{30\}$ \\
\hline & Absence & 77.27 & 120.76 & 100.38 \\
\hline & & $(31.02)$ & $(34.76)$ & $(39.30)$ \\
\hline & & $\{15\}$ & $\{17\}$ & $\{32\}$ \\
\hline \multirow{3}{*}{\multicolumn{2}{|c|}{$\begin{array}{l}\text { Main Effect: } \\
\text { Risk Disclosure }\end{array}$}} & 79.20 & 105.43 & 92.74 \\
\hline & & (25.54) & $(33.66)$ & (32.57) \\
\hline & & $\{30\}$ & $\{32\}$ & $\{62\}$ \\
\hline
\end{tabular}

Panel B: ANOVA Results (DV = Investor Judgments)

\begin{tabular}{|l|c|c|c|c|c|}
\hline \multicolumn{1}{|c|}{ Source } & Sum of Square & d.f. & Mean Square & F-Ratio & p-value \\
\hline Risk Disclosure & & & & & \\
\hline BODs Oversight Disclosure (BOD) & 9826.477 & 1 & 9826.477 & 12.550 & 0.001 \\
\hline Interaction (Risk Disclosure x BOD) & 5211.640 & 1 & 3211.640 & 4.102 & 0.047 \\
\hline Error & 45412.659 & 58 & 782.977 & & \\
\hline
\end{tabular}

Risk Disclosure $=$ Disclosure on high or low level of operational and financial risk exposure. BODs Oversight Disclosure $(\mathrm{BOD})=$ Absence or presence of BODs oversight disclosure.

Investor Judgments $=\mathrm{A}$ combined measure of Attractiveness and Investment.

- Attractiveness: How attractive is the stock of SW, Inc. as an investment opportunity?

- Investment: How likely would you invest in SW stock?

Advances in Accounting Behavioral Research, Vol 18 (2015): pg. 33-68. DOI. This article is @ Emerald (JAI Press) and permission has been granted for this version to appear in e-Publications@Marquette. Emerald (JAI Press) does not grant permission for this article to be further copied/distributed or hosted elsewhere without the express permission from Emerald (JAI Press). 
NOT THE PUBLISHED VERSION; this is the author's final, peer-reviewed manuscript. The published version may be accessed by following the link in the citation at the bottom of the page.

Table 8. Supplementary Analyses

Panel A: Risk Disclosure Condition

\begin{tabular}{|c|c|c|c|}
\hline Measures of Information Usage & $\begin{array}{l}\text { High Risk } \\
\text { Disclosure }\end{array}$ & $\begin{array}{l}\text { Low Risk } \\
\text { Disclosure }\end{array}$ & $t$-test \\
\hline \multicolumn{4}{|c|}{$\begin{array}{l}\text { Among the following disclosure information provided to you, please indicate which one (s) you used for your } \\
\text { investment decision? (Fill in each blank; amounts should total to } 100 \% \text { ) }\end{array}$} \\
\hline - $\quad$ Risk Disclosure & $29.50(16.73)$ & $17.66(8.71)$ & $p=0.001$ \\
\hline Operational and Financial Risk Disclosure & $29.17(11.23)$ & $20.94(7.56)$ & $p=0.001$ \\
\hline Other Risk Disclosure* & $8.83(5.83)$ & $10.16(5.16)$ & $p=0.347$ \\
\hline - $\quad$ Board Oversight of Enterprise Risk & $10.71(1.96)$ & $7.66(9.50)$ & $p=0.400$ \\
\hline - Stock Returns & $21.50(6.97)$ & $24.06(9.63)$ & $p=0.237$ \\
\hline - $\quad$ Financial Ratios & $24.67(7.65)$ & $32.66(10.08)$ & $p=0.001$ \\
\hline - Other Information ** & $14.50(16.94)$ & $17.97(11.21)$ & $p=0.343$ \\
\hline
\end{tabular}

Panel B: BOD Oversight Disclosure Condition

\begin{tabular}{|l|c|c|c|}
\hline \multicolumn{1}{|c|}{ Measures of Information Usage } & $\begin{array}{c}\text { Presence of } \\
\text { BOD } \\
\text { Oversight } \\
\text { Disclosure }\end{array}$ & $\begin{array}{c}\text { Absence of } \\
\text { BOD } \\
\text { Oversight } \\
\text { Disclosure }\end{array}$ & $t$-test \\
\hline $\begin{array}{l}\text { Among the following disclosure information provided to you, please indicate which one(s) you used for } \\
\text { your investment decision? (Fill in each blank; amounts should total to 100\%) }\end{array}$ \\
\hline$-\quad$ Risk Disclosure & $20.17(7.71)$ & $26.41(18.24)$ & $p=0.088$ \\
\hline$-\quad$ Board Oversight of Enterprise Risk & $18.00(6.38)$ & $0.00(0.00)$ & $p=0.000$ \\
\hline$-\quad$ Stock Returns & $23.50(4.76)$ & $22.19(10.92)$ & $p=0.547$ \\
\hline$-\quad$ Financial Ratios & $24.67(5.07)$ & $32.66(11.49)$ & $p=0.001$ \\
\hline
\end{tabular}

Panel C: Regression Analyses (DV = Investor Judgments)

$D V_{i}=\alpha_{i}+\beta_{1 i} \times$ Risk $_{i}+\beta_{2 i} \times$ Board $_{i}+\beta_{3 i} \times$ Returns $_{i}+\beta_{4 i} \times$ Ratios $_{i}+\beta_{5 i} \times$ Others $_{i}+\varepsilon_{i}$

\begin{tabular}{|c|c|c|}
\hline & High Risk Disclosure Condition & Low Risk Disclosure Condition \\
\hline Constant & $\begin{array}{c}a_{1}=105.212, \text { s.e } e=22.651 \\
(p=0.000)\end{array}$ & $\begin{array}{c}a_{1}=247.855, \text { s. } e=81.956 \\
(p=0.0005)\end{array}$ \\
\hline Risk Disclosure (Risk) & $\begin{array}{c}b_{1}=-1.027, s . e=0.298 \\
(p=0.002)\end{array}$ & $\begin{array}{c}b_{1}=-1.609, s . e=1.158 \\
(p=0.176)\end{array}$ \\
\hline $\begin{array}{l}\text { Board Oversight of Enterprise } \\
\text { Risk (Board) }\end{array}$ & $\begin{array}{c}b_{2}=-0.586, s . e=0.440 \\
(p=0.196)\end{array}$ & $\begin{array}{c}b_{2}=-1.475, \text { s.e } e=0.649 \\
(p=0.031)\end{array}$ \\
\hline Stock Returns (Returns) & $\begin{array}{c}b_{3}=0.819, s . e=0.624 \\
(p=0.202)\end{array}$ & $\begin{array}{c}b_{3}=-2.645, s . e=1.714(p= \\
0.134)\end{array}$ \\
\hline Financial Ratios (Ratios) *** & $\begin{array}{c}b_{4}=-0.307, s . e=0.613 \\
(p=0.621)\end{array}$ & ------------------------- \\
\hline Other (Others) $* * * *$ & ----------------------------- & $\begin{array}{c}b_{5}=-2.174, s . e=1.267 \\
(p=0.098)\end{array}$ \\
\hline$R^{2}$ & 0.374 & 0.195 \\
\hline
\end{tabular}

\section{Endnotes}

1 The Security Exchange Commission (SEC, 2000) press release concerning former Chairman Laura Unger's comments on fair disclosure can be retrieved from http://www.sec.gov/news/speech/spch387.htm.

Advances in Accounting Behavioral Research, Vol 18 (2015): pg. 33-68. DOI. This article is @ Emerald (JAI Press) and permission has been granted for this version to appear in e-Publications@Marquette. Emerald (JAI Press) does not grant permission for this article to be further copied/distributed or hosted elsewhere without the express permission from Emerald (JAI Press). 
NOT THE PUBLISHED VERSION; this is the author's final, peer-reviewed manuscript. The published version may be accessed by following the link in the citation at the bottom of the page.

2 Major risk disclosure regulations pertain to accounting for derivative instruments and hedging activities (SFAS No. 133, FASB, 1998), disclosures about segments of an enterprise and related information (SFAS No. 131, FASB, 1997), contingencies (SFAS No. 5, FASB, 1975), postretirement benefits other than pensions (SFAS No. 106, FASB, 1990), small and medium sized entities' exposures to certain significant risks and uncertainties (SOP No. 94-6, AICPA, 1994), forward-looking qualitative and quantitative market risk (FRR No. 48, SEC, 1997), and transfers of financial assets and extinguishments of liabilities (SFAS No. 140, FASB, 2000) (Dobler, 2008; Koonce et al., 2005).

3 Distrust has been shown to be strongly linked to risk perception (Slovic, 1993, p. 675-676).

${ }^{4}$ Inherent risk is the risk that a financial statement will contain material error or misstatement when related internal controls are not present or effectively implemented (AICPA, 2006, p. 1652).

${ }^{5}$ Hodge and Pronk (2006; p. 272) note that professional investors (analysts) generally have well-defined valuation knowledge and use their expertise to focus on financial information and disclosures that they perceive relevant to their investment judgments. In contrast, nonprofessional investors (e.g., MBA students) have relatively ill-defined valuation knowledge and fail to identify specific financial information for investment judgments. Stock market investors fall in-between these two categories because (1) they are not as expert (or sophisticated) as professional investors who specialize in valuation analyses, but (2) they are more expert than non-professional investors as their investment experience stems from engaging in investment of stocks on a regular or professional basis as compared to nonprofessional investors' investment experience, which results from general business work experience and completion of business courses (Victoravich, 2010).

${ }^{6}$ Of the 62 participants, 17 participants work at investment banks, 17 work at commercial banks or commercial bank trust departments, 13 work at brokerage firms, 4 work in accounting firms, and 11 work in corporate financial positions.

7 Despite the marginally significant relationship between Investor Judgments and Undergraduate Major, results of Tukey's HSD test procedure reveal that the average Investor Judgments of finance majors (Mean $=101.88$, s.d. $=30.19$ ) is not significantly greater than the average Investor Judgments of accounting majors (Mean $=81.38$, s.d. 44.62) $(p=0.469)$, business administration majors (Mean $=94.50$, s.d. 28.21) $(p=0.957)$, or others (Mean=71.88, s.d. 26.72) $(p=0.124)$. Given the marginally significant relationship between Investor

Advances in Accounting Behavioral Research, Vol 18 (2015): pg. 33-68. DOI. This article is @ Emerald (JAI Press) and permission has been granted for this version to appear in e-Publications@Marquette. Emerald (JAI Press) does not grant permission for this article to be further copied/distributed or hosted elsewhere without the express permission from Emerald (JAI Press). 
NOT THE PUBLISHED VERSION; this is the author's final, peer-reviewed manuscript. The published version may be accessed by following the link in the citation at the bottom of the page.

Judgments and Undergraduate Major, we tested hypotheses using a 2 $\times 2$ design with Undergraduate Major as a covariate. The ANCOVA results are statistically similar to the results associated with a $2 \times 2$ design without the covariate.

${ }^{8} \mathrm{~A}$ total of 136 upper division accounting and/or business major students from one public university and two private universities in the Midwest participated in a pilot test of the experimental material. Based on the pilot test results, we concluded that the experimental manipulations were effective.

9 The 160 listed firms represent the largest economies with the largest domestic market capitalization in North America and Europe, respectively (Dobbler et al., 2011, p. 2).

10 Non-financial risks disclosed in the annual report of a Fortune 500 company (a food manufacturing company) consist of regulatory risk, technology risk, food quality and safety risk, management risk, and intellectual property rights risk. This information was provided to participants across the four treatment conditions.

${ }^{11}$ In the condition with BODs oversight disclosure, participants were informed that (1) all members of the board are independent directors and former/current top executives of Fortune 500 companies with expertise and business experience, (2) Audit Committee members are financial experts (i.e., Certified Public Accountants), and (3) the board of directors held 8 annual meetings and all of the incumbent directors attended at least $75 \%$ of the total number of annual board meetings.

12 Among the 13 items related to risk perception from the decision-theory and behavioral perspectives, we only used 11 items, omitting Voluntary and Immediacy. The question about Voluntary is related to investment judgments if a person is not aware of operational and financial risk items. We excluded Voluntary because we believe this question may induce early anticipation of investment judgment when participants are instructed to make investment judgments after evaluating information on risk disclosure and BODs oversight role, if required. The question about Immediacy is related to whether a person can ascertain the occurrence of operating and financial risk scenarios in an immediate future or over time. We believe that it is difficult to forecast how soon or late operating and financial risk exposure scenarios might occur due to the lack of specific disclosure information in this regard. As a result, we also chose to exclude this item.

${ }^{13}$ A confirmatory factor analysis was conducted on the items to test dimensionality using a VARIMAX rotation for Eigen values greater than 1.0. The use of the factor analysis was supported by the Kaiser-MeyerOlken (KMO) measure of sample adequacy, which was in the acceptable $(>0.6)$ range $(\mathrm{KMO}=0.653)$ (Hutcheson $\&$ Sofronious,

Advances in Accounting Behavioral Research, Vol 18 (2015): pg. 33-68. DOI. This article is @ Emerald (JAI Press) and permission has been granted for this version to appear in e-Publications@Marquette. Emerald (JAI Press) does not grant permission for this article to be further copied/distributed or hosted elsewhere without the express permission from Emerald (JAI Press). 
NOT THE PUBLISHED VERSION; this is the author's final, peer-reviewed manuscript. The published version may be accessed by following the link in the citation at the bottom of the page.

1999), and Bartlett's test of sphericity, which was significant ( $p<$ $0.001)$.

Advances in Accounting Behavioral Research, Vol 18 (2015): pg. 33-68. DOI. This article is (C) Emerald (JAI Press) and permission has been granted for this version to appear in e-Publications@Marquette. Emerald (JAI Press) does not grant permission for this article to be further copied/distributed or hosted elsewhere without the express permission from Emerald (JAI Press). 